IZA DP No. 9177

Christianity and Infant Health in India

Nidhiya Menon

Kathleen McQueeney

July 2015 


\title{
Christianity and Infant Health in India
}

\author{
Nidhiya Menon \\ Brandeis University \\ and IZA \\ Kathleen McQueeney \\ Brandeis University

\section{Discussion Paper No. 9177 \\ July 2015} \\ IZA
P.O. Box 7240
53072 Bonn \\ Germany \\ Phone: +49-228-3894-0 \\ Fax: +49-228-3894-180 \\ E-mail: iza@iza.org
}

Any opinions expressed here are those of the author(s) and not those of IZA. Research published in this series may include views on policy, but the institute itself takes no institutional policy positions. The IZA research network is committed to the IZA Guiding Principles of Research Integrity.

The Institute for the Study of Labor (IZA) in Bonn is a local and virtual international research center and a place of communication between science, politics and business. IZA is an independent nonprofit organization supported by Deutsche Post Foundation. The center is associated with the University of Bonn and offers a stimulating research environment through its international network, workshops and conferences, data service, project support, research visits and doctoral program. IZA engages in (i) original and internationally competitive research in all fields of labor economics, (ii) development of policy concepts, and (iii) dissemination of research results and concepts to the interested public.

IZA Discussion Papers often represent preliminary work and are circulated to encourage discussion. Citation of such a paper should account for its provisional character. A revised version may be available directly from the author. 


\section{ABSTRACT}

\section{Christianity and Infant Health in India*}

This paper studies child health in India focusing on differences in anthropometric outcomes between the three main religions - Hindus, Muslims and Christians. The results indicate that Christian infants have higher height-for-age z-scores as compared to infants of other religious identities, and that this is especially true for infant girls in states with a relatively large Christian presence. We instrument for Christian identity today using data on the location of Protestant and Christian missions, the incidence of epidemic diseases and natural disasters, and political crises (wars) that mission establishing countries were engaged in during India's colonial history. The results are robust to a series of checks for instrument validity and omitted variables, and indicate that by inculcating awareness and spreading knowledge on sanitation and the scientific underpinnings of disease, the advent of Christianity has longterm health implications for India's children today.

JEL Classification: $\quad$ O12, I15, Z12

Keywords: $\quad$ child health, religion, Christian, Hindu, Muslim, India

Corresponding author:

Nidhiya Menon

Department of Economics

MS 021, Brandeis University

Waltham, MA 02454

USA

E-mail: nmenon@brandeis.edu

\footnotetext{
* Thanks to Anand Swamy, Chris Udry, and Federico Mantovanelli for helpful conversations, and to participants at the Brandeis faculty workshop for comments on an earlier draft. The usual disclaimer applies.
} 


\section{Motivation}

Indian children are among the most undernourished in the world; rates of stunting and wasting are higher than in some sub-Saharan African countries with lower levels of per capita income and higher levels of infant mortality (Deaton and Dreze 2009; Jayachandran and Pande 2014). High malnutrition rates have persisted in India despite impressive gains in economic growth that followed the liberalization of the early 1990s, which led to substantial declines in poverty. This paper investigates why child development has remained insulated from these gains by studying differences in child health outcomes by religious affiliation. Such affiliation is likely to provide information on the likely dietary restrictions encountered by a child in his or her early years, on possible differences in women's control over household resources, and on the child's exposure to fasting in utero during the Muslim holy month of Ramadan. Unlike previous work that has considered Hindu versus Muslim differences in infant and child health (Bhalotra et al. 2010, Brainerd and Menon 2015) however, the focus of this study is the relatively improved health status of Christian children, particularly girls in the southern states of India, which we argue is tied to historical antecedents of Christian missionary work and the egalitarian ideas it propagated.

The comparatively better health status of Christian children is clearly evident in Figure 1 which depicts locally weighted scatterplot smoothed graphs on the association of child's height for age and age in months for four different sub-groups of the population demarcated by religious affiliation. These plots include vertical lines distinguishing ages 0-11 months, 12-23 months and 24-35 months - the first three years of life. The pattern in the sample for all children highlights the advantage of Christian infants in comparison to lower-caste Hindu, upper-caste Hindu and Muslim infants. Beyond infancy however, the Christian relative advantage dissipates and is indistinguishable from the other groups (with some weak suggestion of a relative decline beyond 40 months). These trends remain the same when the sample is restricted to just boys or just girls with the relative advantage in the height-for-age (HFA) measure most evident in infancy (there is some dip for Christian boys at about 30 months whereas this is not true for Christian girls; the relative decline in height-for-age beyond 40 months is more stark for Christian girls as compared to Christian boys however). The last panel of Figure 1 shows relative trends in height-for-age 
for Christian girls and boys - in infancy, girls clearly dominate boys but again, this advantage declines with age. The graphs in Figure 1 underline three things: (1) in relation to Hindus and Muslims, Christian children have a clear advantage in height-for-age particularly in infancy and these trends are distinct. (2) In so far as infancy is a critical time of child development and the age-window that is most reflective of things that occurred in utero and of mother's health (possibly reinforcing and/or remedial actions of parents and the child's environment are likely to come into play only beyond this age), these patterns suggest that historical factors related to the health, education and welfare of Christian women are likely to be important explanations, and (3) Even within the subset of Christian children, girls compare favorably to boys, perhaps echoing the intergenerational advantage of Christian women (in relation to other groups) and the relative health benefits they bequeath to daughters. This paper analyzes these patterns in early child health and argues that Christian missionary work in colonial India is an instrumental explanatory factor.

We focus on children from birth to three years of age as recent evidence demonstrates that negative health shocks in this period can have large, long-lasting effects (Currie and Vogl 2013). Within this short span, infancy to about two years of age is the window of time when growth is fastest in terms of physical and mental development, and health in early childhood (often by age two) is considered to be one of the best predictors of adult earnings, well-being and skill formation (Behrman and Rosenzweig 2004, Cunha and Heckman 2007, Behrman 2009). Given the demands on data, a large part of this evidence has previously focused on children in the developed world. However, children in developing countries may be even more vulnerable because of the widespread prevalence of nutritional and environmental insults, and the frequency with which these occur. Negative health shocks to children in poor countries have only recently begun to receive attention in the economics literature (Jayachandran 2009, Almond and Mazumder 2011, Currie and Vogl 2013, Brainerd and Menon 2014, Brainerd and Menon 2015).

The basic data set that we use is the two earlier rounds of the Demographic and Health Surveys (DHS) for India from 1992 and 1998 as these rounds have publicly available district level identifiers 
(unlike the most recent 2005 round). The DHS surveys provide detailed data on child, mother, and father characteristics, including detailed fertility histories of women aged 15 to 49 . The year of birth of children in these two earlier rounds is approximately 1988-2000. These data are supplemented with several historical sources including a record of all Protestant and Catholic missions operating in India from the mid-1400s, numbers on mortality from cholera, fever, and injuries (including accidents, suicides and snake-bites) from 1864 onwards, occurrences of phenomena such as famines (and their duration), earthquakes and cyclones from 1500s on, and information on civil and international wars fought by countries establishing missions during the years they were active in pre-independent India. Focusing on height-for-age, an indicator of child health that is considered to be a long-run measure of development (and more stable in the short-run that weight-for-age or weight-for-height), our results indicate that when Christian religious affiliation today is instrumented with historical factors influencing missionary work, Christian infant girls score significantly higher than lower-caste Hindu infant girls. Upper-caste Hindu infant girls do likewise, but the coefficient on Christian children is significantly larger in magnitude (about 3 standard deviations to 0.3 standard deviations). This result is impervious to a variety of controls (such as mother's education, child's size at birth (which is used to proxy for mother's height which is not collected in the 1992 round), age at marriage, access to sanitary facilities and household assets, child's birth order, nursing history, prenatal care and disease incidence) and robustness checks, and becomes even stronger when only states with relative large Christian presence are considered. Although the coefficient for Christian infant boys is comparable in size, it may be measured imprecisely for reasons discussed below.

While a Muslim advantage in child survival in India is well-known (Bhalotra et al. 2010, Brainerd and Menon 2015), these patterns regarding the health of Christian infants girls is, to the best of our knowledge, newly documented. As we discuss below, these results for Christian girl infants is especially surprising for India where Christians are a minority group (about 8 percent of the population) and where son-preference results in the preferential treatment of boys beginning in utero (Bharadwaj and Lakdawala 2012) and extending after-birth (Jayachandran and Kuziemko 2011, Barcellos et al. 2014). 
This study contributes to the discussion on child health in India by demonstrating that in addition to current day factors, historical antecedents that may have changed practices and behavior in a propitious manner for one section of the population deserve consideration.

\section{Related literature}

Religion plays an important role in India. The main religious communities are Hindus and Muslims with Christians forming the second largest minority group. The proportion of Hindus (both upper and lower-caste) is about 78 percent in our sample, Muslims are 14 percent and Christians are 8 percent (there are other groups such as Jains who form a tiny proportion of the population and are excluded for purposes of this study). Religious practices differ in a number of ways between Hindus, Muslims and Christians: upper-caste Hindus strictly adhere to a vegetarian diet and Muslims do not consume pork and fast during daylight hours in the holy month of Ramadan (including pregnant Muslim women). Christians also fast during certain religious times but in general, have few dietary restrictions. It is widely acknowledged that there are significant differences among the three groups in women's education and health status, personal health and hygiene and access to medical care. In particular, while Muslim and Christian women tend to be taller than lower-caste Hindu women, Muslim women are comparatively less literate, marry at a younger age, and are less likely to work. Christian women have the highest rates of literacy in our sample, marry at older ages, and work at rates higher than those of uppercaste Hindu and Muslim women.

A few recent papers demonstrate that religious practices affect the health outcomes of infants and young children. Almond and Mazumder (2011) show that fasting during Ramadan by pregnant Muslim women is linked with lower birth weights and lower proportion of male births for individuals who were in utero during Ramadan. Adults who were in utero during Ramadan are also found to have a higher incidence of symptoms associated with chronic diseases such as type 2 diabetes and coronary heart disease (van Ewijk 2011). Further, Bhalotra et al. 2010 shows that within India, Muslim children have a significantly higher probability of survival in infancy than do Hindu children, despite their lower socioeconomic status. Brainerd and Menon (2015) demonstrate that this advantage does not persist 
beyond infancy however. Perhaps closest in spirit to our study is a recent working paper by Calvi and Mantovanelli (2014) which studies the effect of being close to a Protestant medical mission in British India and health outcomes for adults today. Using geocoding techniques to measure minimum distance between the location of individuals today and the location of Protestant health facilities in the nineteenth century, the study finds that proximity to historical medical missions beneficially affects adult health (as measured by BMI) today. The analysis does not focus on children however, and given GIS demands, is restricted to cross-sectional data from seven states in India. Beyond these few papers, there is little work that investigates the impact of religion on child health in India.

Our paper contributes to the literature in several ways. First, using geo-referencing and other techniques we compile a historical data set at the district level on the location of Protestant missions, Catholic missions, occurrence of health shocks associated with epidemic diseases and large natural disasters, and wars that countries locating missions in India were engaged in, from approximately 1450 to 1910. These data allow us to causally measure Christianity's influence on child height-for-age today based on history from colonial India. Second, these data allow us to show that in a country with strong son-preference and in which Christians are a minority group, Christian infants, especially girls, do particularly well as compared to lower-caste Hindu infants and even upper-caste Hindus and Muslim infants. This is new and relevant to the debate on causes of child malnutrition in India as previous research has documented the strong link between health measures at birth (and in infancy) and long-term health and labor market outcomes. Third, compared to Islam, Christianity came relatively late to India, and importantly, it was mostly lower-caste groups that converted to Christianity in the years we consider (discussed more below). Hence rather than arising from a separate heterogeneous population, today's Christians in India originated from a similar genetic make-up to Hindus in the region, indicating that differences in child health outcomes among these groups are most probably due to behavior and not genetic dissimilarities. These results add to the literature that underlines the importance of behavior in choice, historical institutions in shaping development today (Nunn 2009; Alesina et al. 2013), and the role of religion in molding socio-economic consequences (Barro and McCleary 2005). 


\section{Christian influence in India}

It is important to understand the mechanism underlying the better health status of Christian children in India and the role that missionary work played. Earliest accounts make clear that it was mostly lower-caste groups that were open to conversion for a variety of reasons including better economic conditions (improvement in education and employment) and increase in status (particularly of women) and self-respect (Pickett 1933). For these disadvantaged groups, conversion meant escape from an oppressive social hierarchical order that now allowed movement into more diversified occupations. For example, “...In the Nagercoil area the Nadars, who when the Christian movement began were confined almost entirely to drawing the juice of the toddy palm ... are now entering every kind of work ..." (Pickett, 1933). These new occupations included tailoring, carpentry, masonry and pottery. In addition to reduction in social oppression and poverty, improved opportunities for education that came with conversion also served as protection against widespread fraud that had been perpetuated against these communities for generations. Further, after conversion, lower-caste groups obtained access to infrastructure such as public roads that had been previously denied to them (Kent 2004).

Although there were many demand side factors that increased the attractiveness of conversion for these communities, there were several supply side factors as well. Lower-caste conversions, particularly in rural areas, often happened in mass during or immediately after periods of economic hardship brought on by the occurrences of famines, natural disasters (cyclones and earthquakes) and epidemic diseases (cholera, fever). The motivation in these circumstances was the material support provided by the missions (Kent 2004). Conversion to Christianity was not absent among the upper-caste groups. However, such conversions occurred in much smaller numbers, often individually, and were driven by ideological motives rather than economic concerns.

What are the mechanisms that may underlie the better health status today of children of converts from more than two centuries ago? In addition to evangelism and teaching of vocational occupations for fostering cottage-industries such as embroidery, lace-work and spinning, lady missionaries and the wives of missionaries taught lower-caste women concepts of germ theory (importance of cleanliness, hygiene 
and sanitation, how to administer medicine, and origins of worms and rashes), the advantages of growing and consuming vegetables in small plots next to their homes, and emphasized that child development and parenting was mainly a mother's responsibility (Kent 2004). The coming of Christianity also led to the prevention and cure of illnesses in many areas. As noted in Picket (1933) "The school-teacher...in a village in the Vidyanagar area, in which malaria is endemic, estimated that in one year the loss of two hundred and twenty-one days of work had been prevented by the distribution of quinine by the teacher among the twenty-nine Christian families." Access to medicine meant that death rates for children were lowest in Christian families. There is also evidence that consumption of alcohol and drugs as well as things such as gambling and child marriage decreased in areas where Christianity spread its influence, and that literacy rates among children were higher in families who had converted to Christianity (Pickett 1933). Hence in addition to subverting caste rules and laws and increasing education, income, and awareness, particularly of mothers through schools and churches, there were several other related aspects of conversion that had the potential to importantly influence child health in the long run.

\section{Instruments}

The paragraphs above clarify that Christianity had strong influences on fostering an environment that would have been beneficial for improving children's long term health and development. We use this information, supplemented with data on other factors, to instrument for Christian religious affiliation today. ${ }^{1}$ Since one is born into one's religion and marriage is restricted to one's caste and faith for the majority of the population, that religious identity is not a choice is less controversial in India. However, as discussed above, there was active conversion to Christianity in colonial times with people exercising this choice in response to a variety of economic and environmental factors. Even though rates of conversion are considerably lower today, these trends in the past are likely to have impacts today especially in the Christian community. There may also be other reasons for why religious identity is not

\footnotetext{
${ }^{1}$ We instrument only for Christian religious identity using historical data since relatively very few Muslims were converted in colonial times and they were only faintly influenced by missions (there is some evidence that Christian missions did not locate in Muslim areas - see Mantovanelli and Calvi (2014)). Although most converts were lowercaste Hindus, Hindus today are also not instrumented as the historical factors we consider would have had the strongest influences over a century ago, less so today.
} 
randomly assigned. For example, omitted variables that are correlated with both religious affiliation and child health status may render the former variable endogenous (the level of income in Christian households may be one such measure). For these reasons we instrument for Christian identity today using a variety of variables that are discussed in detail next.

\section{Location of Protestant and Catholic missions}

Missions, whether Protestant or Catholic, may have positive implications for child health for reasons discussed above. We use the Statistical Atlas of Christian Missions published in 1910 to gather information on the location of all Protestant missions in India as of that year. This source was compiled for the World Missionary Conference in 1910 in Edinburgh, Scotland, and is a directory of missionary societies, maps of mission fields and an index of mission stations throughout the world. Using this Atlas, we geo-referenced the India maps in ArcGIS and then superimposed them onto a map of India with 2001 district boundaries to gather data on the location of missions at the district level (India in 2001 had 593 districts). This information is then supplemented with data from the Encyclopedia of Missions from 1904 to find the year in which the mission was established, the district of location as of 1910 , and the country that was responsible for its establishment. We have complete information for 1004 Protestant missions throughout India. Map 1 shows the location of Protestant missions in the southern plate for India as of 1910, and is an example of a map from the Statistical Atlas that was geo-coded.

Location of Catholic missions is obtained from the Atlas Heirarchichus, compiled by the Vatican, to provide data on the universe of Catholic missions throughout the world as of 1911. The India related maps from this source were similarly geo-coded to gather data at the district level on the location of Catholic missions in the country. In addition to the location, this source also provides information for most of the missions on the year of founding, and the mission society and country that was responsible for its establishment. Using the Encyclopedia of Missions, we supplemented data on year of origin and country of establishment for the remaining missions in this list. The Catholic missions also have additional information on numbers of priests (whether external or native/indigenous), the number of auxiliary missionaries (Laien brothers, Schwestern Sisters, Katechisten), number of theological schools 
and seminaries, numbers of elementary schools and schools of higher degrees with breakdown of students by gender, number of hospitals, pharmacies and print shops. ${ }^{2}$ The variables are used in the robustness checks of our estimates and as shown below, are influential in explaining some of the patterns we document. We have complete information for 290 Catholic missions throughout India. Map 2 from Atlas Heirarchichus shows the location of Catholic missions in southern India as of 1911, and is an example of the map that was geocoded to get information on such missions in this region of India.

A concern with using mission location information alone is that location may be endogenous. Missionaries may have chosen to work in areas that were easily accessible, more amenable climate-wise, or where the local population was systematically different and so more open to conversion (poor areas with high density of people) (Nunn 2010, Cage and Rueda 2013). We control for the endogeneity of mission location by using, amongst others, variables from three geo-referenced maps from Constable's Hand Atlas of India 1893. These include the number of cities at or above 1500 feet, number of cities on railway lines and the number of cities on navigable canals. The creation of these variables is similar to the creation of the variables measuring location of Protestant and Catholic missions, and is also accomplished at the district level.

Mortality from disease epidemics

As noted in Pickett (1933) and Kent (2004), times of economic hardship that coincided with the incidence of epidemic diseases were major drivers of mass conversions of lower-caste groups to Christianity. The Government of India published the Annual Report of the Sanitary Commissioner with the Government of India from 1864 to 1919 (we only have access from 1868 onwards, are missing a couple of years in between, and stop as of 1910 to be consistent with the mission location data that we have) that compiles information at the British province level on deaths due to diseases such as cholera, smallpox, fever, dysentery and diarrhea, plague, respiratory diseases, injuries (including suicides, wounding, accidents, deaths from snake and animal bites) and all other causes. Importantly, these data

\footnotetext{
${ }^{2}$ These are at the Archdiocese, Diocese and Apostolia Prefecture levels, but we know which Catholic mission districts fall under each of these categories.
} 
are provided at a level that controls for the size of population in these provinces. For example, there is complete information for ratio of deaths from cholera per 1000 people, and likewise for deaths on a ratio basis for the other diseases noted above (cholera and fever are the only ones that are consistently measured however). These data are used to control for province and year level variation (we think of these as "triggers") for conversion to Christianity. These British provinces include the Bengal Presidency, Assam, North Western Provinces, Punjab, Oudh, Central Provinces, Berar, Rajputana, Central India, the Madras Presidency, the Bombay Presidency and Hyderabad. These mostly remain the same throughout the years except for a splintering in later years of Oudh into the United Provinces of Agra and Oudh, and Rajputana into Rajputana Ajmer and Merwara. The largest causes of mortality in British India were fever, plague, dysentery and cholera, but as noted above, only cholera and fever are measured consistently over years.

\section{Occurrence of famines and other natural disasters}

In addition to the occurrence of epidemics, other times of economic hardship that served as catalysts for large-scale conversion and that are noted in historical texts such as Pickett (1933), Kooiman (1988) and Kent (2004) are famines and natural disasters including cyclones and earthquakes.

Information on the occurrence of famines (and their intensity) in the provinces of British India from 1770 to 1910 were compiled from several sources including British Parliamentary Papers, various years, Report of the Indian Famine Commission, various years, Imperial Gazetteer of India, various years, and McAlpin 1983. Given their unexpectedness and frequency, the natural disasters that we focus on include cyclones and earthquakes. Data on the occurrence of these in the provinces of British India from 1584 to 1910 were collected from a variety of sources including the Bengal District Gazetteers, Imperial Gazetteer of India, Davis 2008, Eliot 1900, Transactions of the Bombay Geographical Society, and the Administration Report of the Indian Telegraph Department for 1885-86. Summary statistics confirm that famines and cyclones were the most common natural disasters in colonial India.

Wars 
The final component of our instrument set is an indicator for all the years in which countries that established Protestant or Catholic missions in India were engaged in wars (including civil wars). Over and above Great Britain (1642-1910), other countries active in mission work in India over this time period include Australia (1853-1910), Belgium (1830-1910), Canada (1874-1910), Denmark (1700-1910), France (1674-1910), Germany (1781-1910), Italy (1604-1910), Portugal (1498-1910), Sweden (18851910), Syria (Ottoman empire 1449-1910) and USA (1831-1910). British Parliamentary Papers reveal that British Government financing was crucial to many operations of the church in India (Episcopal, Presbyterian and Roman Catholic) including resources to be used for salaries of bishops, archdeacons, chaplains, house rent, travel expenses, and even allowances for furniture and building repair. ${ }^{3}$ Expenditure on clergy was also part of the military department for ecclesiastical purposes. Our intuition in using information on wars that countries fought in specific years is to proxy for disturbances in such support for the church in India during those years. It is likely that during times of war, all available resources would be mobilized for the war effort. These are thus political factors that lead to exogenous declines in support for church operations, indirectly affecting the efficacy of mission work in India. Using historical sources including the Encyclopedia of Wars for each country, we find that Britain engaged in 56 wars, Australia in 2 wars, Belgium in 6 wars, Canada in 7 wars, Denmark in 10 wars, France in 54 wars, Germany in 12 wars, Italy in 11 wars, Portugal in 27 wars, Sweden in none, Syria (Ottoman) in 99 wars, and the US in 46 wars, in the years these countries were present in India.

Information on wars by country and year are then merged with data on the location of missions by country (of establishment) and year (the mission location data has current district information as well). Similarly, occurrences of famines and natural disasters are merged with data on mortality from diseases at the province and year level. Finally, we create the full data set of instruments by merging the two composite data sets on the basis of provinces (district and location of mission is used to trace its province) and year (which in the former data set is year of establishment of the mission). We also use information

\footnotetext{
${ }^{3}$ For example, between 1830 and 1836, the British government spent Rupees 3,296,916, an appreciable amount today, but especially then, on support of the Episcopalian church in just three Provinces - Bengal, Madras and Bombay.
} 
from the 1901 census of India on average population per square mile, population per square mile in cities, proportion supported by industry per 1000 of population, number of females afflicted by blindness per 1000 of population, number of literate males and females per 1000 of population, and number per 10,000 of population who were immigrants when enumerated (to control for migration). These variables are used as robustness checks (discussed below) and are merged with the data set of instruments on the basis of provinces in colonial India, as the 1901 census does not report statistics for these variables at a more disaggregate (district) level.

\section{Two Stage Least Squares Methodology}

We begin by using linear regression models to investigate the impact of religion on children's anthropometric outcomes. The OLS empirical specification takes the following form:

$$
\begin{gathered}
H_{i j t}=\beta_{0}+\beta_{1} \text { UpHindu }_{i j t}+\beta_{2} \text { Muslim }_{i j t}+\beta_{3} \text { Christian }_{i j t}+\beta_{4} X_{i j t}^{c}+\beta_{5} X_{i j t}^{w}+\beta_{6} X_{i j t}^{h}+\beta_{7} X_{i j t}^{H H} \\
+\beta_{8} X_{j t}+\beta_{9} M+\beta_{10} T^{c}+\beta_{11} T+\beta_{12} S_{j}+\beta_{13}\left(T x S_{j}\right)+\varepsilon_{i j t}
\end{gathered}
$$

where $H_{i j t}$ denotes height-for-age (HFA) for child $i$ in state/district $j$ in year $t, U p H i n d u_{i j t}$ is a dummy variable for the upper-caste Hindu religious affiliation of the child's household, Muslim ${ }_{i j t}$ is a dummy variable for Muslim affiliation, Christian ${ }_{i j t}$ is a dummy variable for Christian affiliation, $X_{i j t}^{c}$ are childspecific indicators (order of birth, gender, whether child was nursed, whether child had diarrhea or cough in the previous two weeks), $X_{i j t}^{w}$ are woman (mother)-specific indicators (measures of maternal health factors such education and work characteristics, prenatal or antenatal check-ups with a doctor, and mother's demographic characteristics including age at first birth, age at first marriage, and general health where height, which is not measured in 1992, is proxied for by size of the child at birth), $X_{i j t}^{h}$ are husband (father)-specific indicators (age, education, and work characteristics), $X_{i j t}^{H H}$ are household-specific indicators (rural/urban indicator, age and gender of household head, indicators for access to electricity and ownership of assets such as refrigerators, motorcycles, and cars, as well as information on sources of drinking water, toilet facilities and years lived in place of residence), and $X_{j t}$ is a state-specific indicator 
(per capita net state domestic product, area under rice and wheat, rainfall, and other variables that are used in the robustness checks including per capita calories, infant mortality rate, Gini coefficient of distribution of consumption, public subsidies and average air temperature). In order to control for time trends, equation (1) includes month of conception dummies $(M)$, year of conception dummies $\left(T^{c}\right)$, a time indicator for the second (1998) round of the DHS data $(\mathrm{T})$, state dummies $\left(S_{j}\right)$, and interactions of time dummy $\mathrm{T}$ and region dummies $S_{j} \cdot \varepsilon_{i j t}$ is the standard idiosyncratic error term, and standard errors are clustered by state. The coefficients of interest are $\beta_{1}, \beta_{2}$, and $\beta_{3}$ : the relative impact of adherence to upper-caste Hindu, Muslim and Christian practices on child health (the excluded category is lower-caste Hindu groups). Results of the OLS models are reported in Tables 2-3.

We then instrument for Christian religious identity using the variables described above leading to a standard two stage least squares (TSLS) empirical framework where the first stage is:

$$
\text { Christian }_{i j t}=\gamma_{0}+\gamma_{1} Z_{i j t}+\vartheta_{i j t}
$$

where subscripts are as described before and $Z_{i j t}$ are the identifying instruments discussed in Section IV. The results of the first stage are reported in Table 4 and results of the TSLS results (including robustness checks) are reported in Tables 5-18.

\section{Data and summary statistics}

We use the two earlier rounds of the Demographic and Health Surveys for India 1992-93 and 1998-99 since these have district identifiers publicly available, and keep children aged three years and below since anthropometrics are reported consistently for this age-group. ${ }^{4}$ These data include maternal education, work and demographic characteristics that are asked of all women between the ages of 15-49, detailed reproductive histories on year and month of delivery of every child born, gender of the child, and information on child height-for-age. These data were then merged with the dataset for historical instruments described above at the state and district level to obtain the full sample for analysis (at the year-state-district level). This sample includes information on 44,116 children, 22,051 that were surveyed

\footnotetext{
${ }^{4}$ The 1998-99 DHS for India only includes anthropometric data for children aged three and younger.
} 
in 1992 and 22,065 that were surveyed in 1998. Table 1 presents summary statistics of child-specific, woman-specific, husband-specific, household-specific and state-specific characteristics in our sample (pooling the data for both survey rounds), separated by religion. At each level (child-specific, womenspecific, household-specific, and state-specific), results are reported for unique observations.

The summary statistics for child height-for-age are shown in the top panel of Table 1 . Heightfor-age z-score measures stunting, and is considered an indicator of long-term health status that fluctuates little in response to short-term changes in diet..$^{5}$ The data in Table 1 indicate that across religious groups, children in India are malnourished by these measures: among upper and lower-caste Hindu children, the average height-for-age $\mathrm{z}$-score is -2.21 ; two standard deviations below the mean of zero is considered to be stunted. Among Muslim children, height-for-age varies along similar thresholds and is notably worse than Hindu children. Christian children have an average height-for-age z-score of -1.56 which is relatively better than children in the other two groups but still substantially lower than the threshold for adequate nutrition. Other measures summarized in Table 1 indicate few notable differences across the four samples by religious affiliation. Breastfeeding rates are high, Muslims tend to have larger families as evident from the summary statistics for the order of birth variable, and children with this denomination are also more likely to have had diarrhea in the last two weeks compared to upper-caste Hindu and Christian children. A sizeable proportion of Muslim children were in utero during Ramadan.

In terms of woman-specific characteristics, Muslim women are less likely to seek prenatal or antennal care and have earlier first births as compared to upper-caste Hindu and Christian women. Average age at first marriage is very young (about 16 years) and youngest among lower-caste Hindu and Muslim women. Alternatively, average age at first marriage is close to 20 years for Christian women. Literacy rates are lowest among low caste Hindu women and highest among Christian women. Christian women are also significantly more likely to report having children who were large at birth (as noted before, we use this measure to proxy for mother's height as the latter is not collected in the 1992 round). Relatively more lower-caste Hindu and Christian women are likely to report they are working, and

\footnotetext{
${ }^{5}$ For all rounds of the DHS data, we use the z-scores based on the revised (2006) WHO growth charts.
} 
women's average age ranges from 26 to 27 years and the average husband's age ranges from 32 to 33 years. Muslim women have husbands with the lowest rates of literacy. Most males report working outside the home in these data. Further, populations are mostly rural, especially for lower-caste Hindus. Summary statistics for other variables indicate that close to 90 percent of households are maleheaded. In terms of the religion variable, among Hindus, 21 percent are lower-caste Hindus and 53 percent are upper-caste Hindus. Reflecting their minority status, about 14 percent of the population is Muslim and about 8 percent is Christian (these statistics are not reported in Table 1). Other indicators of ownership of consumer durables (refrigerator, motorcycle, car) suggest that on average, the status of upper-caste Hindu and Christian households is relatively better than that of lower-caste Hindu and Muslim households. This is underscored when access to electricity, access to piped water for drinking (a relatively clean source) and to some extent, access to better sanitation through flush toilets, is taken into account. In these data, Hindu households are likely to report relatively fewer years lived in place of current residence, which is still quite high at 11-12 years.

Table 1 also reports summary statistics for state-specific characteristics for all states and those with larger Christian presence (Andhra Pradesh, Goa, Karnataka, Kerala, Maharashtra and Tamil Nadu about 21 percent of the sample) including variables used in the robustness checks, variables used to control for the endogeneity of the location of missions, the instruments and the 1901 census variables. Information on per capita GDP for India is collected from the Economic Organization and Public Policy Program (EOPP) database at the London School of Economics. Rice and wheat cropped area, controls for nutrition and possibly, the agricultural structure of occupations at the state level, were obtained from the Statistical Abstract of India and Area and Production of Principal Crops in India, various years. Information on malaria and TB deaths are collected from different editions of India's Statistical Yearbooks, Agricultural Statistics, and Vital Statistics of India. Data on rainfall and air temperature is collected from the Indian Meteorological Department, and the time-varying consumer price index (CPI) for India is for agricultural laborers (base: 1986-87=100) and is collected from the Statistical Yearbook of India 2013 and the Statistical Pocketbook of India 2002. Data on per capita calories, per capita proteins 
and per capita fat per day is from Reserve Bank of India publications, various years. Infant mortality rate data was obtained from the Sample Registration System Bulletin, various years, and measures of inequality and national central assistance (public subsidies) are from the Planning Commission of India.

Table 1 also reports descriptive statistics for number of elevated cities, number of cities on railway lines, and number of cities on navigable canals in districts as of 1893. Statistics on locations of Protestant and Catholic missions in India indicate that on average, there were about three Protestant missions and one Catholic mission per district. As a control for time, we also include the difference between year of birth of the child and the earliest year of establishment of either a Protestant or Catholic mission in the child's district of residence. This variable is about 141 years for Protestant missions and close to 102 years for Catholic missions. The variable that measures the total number of wars each country establishing missions in India was engaged in averages about 6 , and statistics are also provided on ratio of deaths per 1000 people from cholera, fever (which is especially high), and injuries at the province-year level, an indicator for an intense famine (where intensity indicates a combination of area in square miles and the population affected) in a province-year, duration of famines, and the incidence of natural disasters such as cyclones (which are especially pervasive) and earthquakes in a province-year. Summary statistics are also reported for the 1901 census variables that we use as robustness checks for the instrumented results, and for information on hospitals, pharmacies, print shops, teachers by denomination and gender, and elementary and higher degree schools in these regions demarcated by religious affiliation and gender of students.

\section{Results}

\section{A. Ordinary least squares (OLS) models}

Tables $2-3$ present the OLS results from the estimation of equation (1) where Christian religious identity is treated exogenously. Results in Table 2 are presented for boys in the full sample and for states with larger Christian presence, by age in months of children disaggregated in 11 month groups. The table reports coefficients on the three included religious groups where the excluded category is lower-caste Hindu children. The first column indicates that in comparison to lower-caste Hindu boy infants, Christian 
and upper-caste Hindu boy infants have a HFA z-score that is .596 and .204 standard deviations higher respectively, holding constant all characteristics of the child, mother, father, household, and state (except those state-characteristics that are used in the robustness checks). Muslim children show no significant difference in this measure of child health in the full sample. The second column reports results for children in the 12-23 month age group and again, upper-caste Hindu children have an advantage over lower-caste Hindu children. Muslim children also do significantly better with a HFA z-score of .142 standard deviations. There are no significant results when the sample is restricted to children in the 24-35 month age group or to states with a large Christian presence as the last four columns of Table 2 show.

Table 3 presents OLS results for girls. The only significant results here are for children in the 2435 month age-group in the full sample of states where Christian girls have an advantage of .324 standard deviations over lower-caste Hindu girls, and Muslim girls are about .2 standard deviations shorter than the comparison group. Restricting the sample to states with large Christian presence shows that few estimates are measured with precision.

\section{B. Two stage least squares (TSLS) models}

\section{First stage results}

Table 4 presents the results for the first stage where the dependent variable is the dummy indicating Christian religious affiliation. The first column reports results only for variables associated with Protestant and Christian missions and shows that the former in particular has strong positive significant impacts on Christian identity today. Difference between the child's year of birth and the earliest year of establishment of Protestant missions which is intended as a measure of length of time of exposure to Protestant missions has the expected positive impact. The negative sign on the interaction between the number of Protestant missions and time exposure suggests that the strongest impact of such missions occurred closer to their year of establishment in the district with "diminishing returns" evident since then. Variables related to Catholic missions show no significance at all in the first column of Table

4. The differences between the impacts of Protestant and Catholic missions in India have been noted before in the context of literacy (Mantovanelli 2014); these results indicate that these missions also differ 
in their influence on Christians in India today.

The second column of Table 4 reports results when the total number of wars establishing countries were engaged in is added to the set of instruments. Although it has the expected negative sign, the variable is insignificant. The three variables associated with Protestant missions remain significant in the expected direction, whereas the Catholic mission variables remain insignificant. The last column of Table 4 adds the natural disaster variables - number of intense famines, length of time famines lasted, number of cyclones and earthquakes, and the ratio of deaths from injuries due to random factors that are not directly correlated to child's height - accidents, suicides, wounding, and animal and snake-bites. Again, the variables related to Protestant missions retain their effects in the expected direction and the variables related to Catholic missions show little significance (except for the exposure variable that is now weakly negative). The total number of wars that mission establishing countries in India are engaged in has a significant negative impact, consistent with the intuition that during these times, fewer resources are available to support missionary activities. The occurrence of intense famines has the expected positive impact which is in keeping with the intuition that during times of economic hardship triggered by such natural disasters, people are more likely to seek alms and the material benefits offered to Christians. Cyclones have the hypothesized effect but is insignificant as is the number of earthquakes. Ratio of deaths from injuries is negative (this variable has some missing observations as it is not consistently recorded in the Sanitary Commissioner's Reports) and measured with error. The F-statistic that these identifying instruments are jointly zero is 39.780 , well above the rule-of-thumb threshold value for sufficiently strong instruments (unlike in the first two columns of this table). The set of instruments used in the analyses that follow hence includes all listed in the third column of Table 4 . To be valid, the instruments need to satisfy the exclusion restriction: they should be correlated with Christian identity today (which is indeed the case as noted in Table 4) but conditional on Christian religious affiliation, have no independent effects on child HFA. We report tests of instrument validity in the second stage results below.

Second stage results 
Tables $5-6$ report the second stage results using the full set of instruments for the total sample and states with relatively large Christian presence for male children separated by age group. In keeping with the tables before, only the religion dummies are reported but the regressions include the full set of child, mother, father and household characteristics, and month and year of conception dummies and time and state dummies (as well as their interactions) as before. Table 5 for boys indicates no significant coefficient except for upper-caste Hindu infants in column one. The case is much different in Table 6 which reports the mirror results for girls. Here, the coefficient on the Christian dummy indicates that in comparison to lower-caste Hindu female infants, Christian infant girls are 3.682 standard deviations taller for their age. This is a large effect and interesting given that Christians today were mostly converts from lower-caste Hindus in colonial India; differences in child health outcomes between these groups now evident in the TSLS results suggest that changes in behavior are likely to drive these outcomes rather than differences in genetics. Upper-caste Hindu infants are also found to have an advantage over lower-caste Hindu female infants but the coefficient is significantly smaller at .245 standard deviations (there is no significance for the Muslim coefficient). The $p$-value associated with Hansen's $J$ statistic, a test of overidentifying restrictions which tests the joint null hypothesis that the instruments are valid (that is, not correlated with the error term and correctly excluded from the estimated second stage) cannot be rejected. The advantage for Christian infants does not persist however as seen in the second and third columns which consider estimates for older girls. In comparison to the OLS results for infant girls in Table 3, these instrumental variable (IV) estimates in the first column are larger (more positive) and measured with less error, indicating a negative bias in the OLS estimates. The results for infants in the first column are echoed in the fourth column that considers estimates for infant girls in states with a large Christian presence. In this case, all three religion dummies are significant and positive but the coefficient on the Christian dummy is significantly larger (a test of over-identifying restrictions still confirm the validity of instruments). Again, these results do not persist as children age. These first set of IV results thus indicate that Christian infant girls in particular score significantly higher than their lower-caste Hindu counterparts, with results for boys in the expected direction but measured less precisely. 


\section{Non-random mission location}

An issue to be taken into account concerns the endogeneity of mission locations. There is evidence that missionaries chose to work in areas that were amenable climate-wise or access-wise (Nunn 2010, Cage and Rueda 2013). In order to control for possible endogeneity in location of both Protestant and Catholic missions, we include three variables to the second stage of the IV regressions. These relate to the number of cities in the district that were at or about 1500 feet (the lowest threshold of elevation from Constable's Hand Atlas of India from which the map is geocoded), and the number of cities in the district on railway lines and on navigable canals. The IV results that include these variables in the second stage are reported in Tables 7 and 8.

Beyond the upper-caste Hindu dummy in the first column of Table 7, there is nothing of significance for boys in the full sample. In states with a Christian presence however, both upper-caste Hindu infants and Muslim infants are found to have an advantage over lower-caste Hindu male infants while the Christian coefficient is insignificant. This regression also shows that number of cities at this elevation has a positive influence on the health of infant boys. The corresponding results for girls are reported in Table 8. With the addition of controls for possible endogeneity in the location of missions, infant Christian girls in the full sample are 3.702 standard deviations taller and Muslim infant girls are .215 standard deviations taller than lower-caste Hindu girls. The size of these coefficients is about the same as compared to the corresponding regression in Table 6 indicating that controlling for endogeneity in mission location did not alter much in this subsample. This is confirmed with a test of significance of the three new additional control variables which indicates that we cannot reject that these are jointly zero. The coefficients in the fourth column of Table 8 which restricts the sample to states with a Christian presence are also close to the corresponding ones in Table 6, again suggesting that the controls for endogeneity in location of missions do not significantly change our original results. The full set of results

for all variables in these regressions is reported in Appendix Tables 1 and 2.

\section{Robustness checks}

Nutrient intake, prices and the disease environment 
The remaining tables in the paper report results from different robustness checks of the estimates for male and female infants in Tables 7 and 8 . Table 9 reports results for infant boys in the full sample and in the Christian sub-sample that includes (in addition to the variables controlling for endogeneity of missions) controls for per capita calories, per capita protein, per capita fat intake, prices (consumer price index for agricultural laborers), and the incidence of malaria and tuberculosis (TB). Table 10 does likewise for infant girls. Examining the impact of food prices on child health is important as previous research has shown (Meng et al. 2009) that nutrient availability can decline due to increased food prices. The positive effect of income growth (as occurred after the 1991 liberalization in India) on nutrient availability may thus be more than offset by changing relative prices as occurred in China in the mid1990s. The results for boys in Table 9 are about the same as before. Controlling for calorie, fat and protein intake as well as prices does not change the relative size of the Christian dummy for infant girls in Table 10 either. However, controlling for malaria and TB significantly increases the size of all three religion coefficients in relation to the HFA z-score of low-caste Hindu girls. ${ }^{6}$

Infant mortality rate, Gini, temperature and public subsidies

Tables 11 and 12 report results for infant boys and girls for the full sample and for the Christian sub-sample when controls are added in the second stage for the infant mortality rate, the Gini, temperature and public subsidies (measured by national central assistance). Results for boys are as above with significance evident for upper-caste Hindu infants and some Muslim significance as well in the smaller sub-sample of the data. The Christian dummy is not significantly different from zero in any of the regressions reported in Table 11. With these controls however, the results for Christian infant girls in Table 12 are all significant with coefficients that are in the same ballpark in terms of magnitude as the comparable runs in Table 8. The upper-caste Hindu dummy also remains significant and comparable in magnitude to those in Table 8 across the eight regressions in Table 12, and the same is true for the Muslim coefficient in the smaller sub-sample of Christian states. In sum, although some of these

\footnotetext{
${ }^{6}$ Malaria and TB information is missing for some states and years and do the sample size for the run that includes this variable in the full data is smaller than before.
} 
additional controls in the second stage are significant (mainly in the smaller sub-sample), they do not absorb the effect of the religion dummies for infant girls.

\section{Colonial diseases, additional famine controls, 1901 census controls}

Diseases in colonial times may independently impact health capital leading to effects on child HFA today, hence breaking the exclusion restriction. Similarly, although the incidence of famine may be exogenously timed, there may be long-lasting consequences on health if the proportion of people affected is large. Moreover, independent impacts on health of children today may also result from differences in region and population characteristics (migration for example) prevalent in colonial India. For these reasons, we include the ratio of deaths from cholera and fever per 1000 people, a measure for the average number of people affected in famines, and controls from the 1901 census of India for the average population per square mile, average population per square mile in cities, proportion supported by industry, number of women with afflictions (blindness), literacy rates for men and women and a control for migration - number per 10,000 of population who were immigrants in the district when enumerated. Results from regressions that include these variables in the second stage are reported in Tables 13 and 14.

Table 13 for infant boys shows little of significance for the Christian coefficient except in the second column. Table 14 for infant girls shows that with some of these controls (famine and 1901 census variables), the Christian coefficient in the full sample is no longer significant. In the sub-sample of Christian states however (where the instruments are likely to have the most power), coefficients on the religion dummies are virtually indistinguishable as compared to before indicating that in this sub-sample at least, patterns persist despite the inclusion of these additional variables.

Number of hospitals, pharmacies, print-shops, male and female teachers

Tables 15 and 16 report results for infant boys and girls with controls in the second stage for additional factors that may independently impact child health today by improving health infrastructure in the past, or through demonstration effects that result from being exposed to teachers of a specific gender. These factors include numbers of hospitals, pharmacies and print-shops, and numbers of indigenous male and female teachers of different denominations. There is some evidence for infant boys and girls in 
Tables 15 and 16 that these matter importantly. Focusing on the girls results that were positive and significant previously, Table 16 shows that these controls absorb all of the significance of the Christian coefficients in the full sample of states and in the smaller sub-sample. This indicates that these controls are mechanisms or explanatory factors for why Christian infant girls have substantially higher HFA zscores over lower-caste Hindu girls. As expected, these variables are orthogonal to the upper-caste Hindu advantage which is still evident in all runs of Table 16.

Number of elementary and higher degree schools and enrollment by gender

The final list of controls we consider also play an explanatory role in providing evidence for why Christian children may have the HFA advantage we document. These variables include numbers of elementary schools, number of schools of higher degrees and enrollment in these schools by gender of children, and by Catholic and non-Catholic denominations. Focusing on the results for infant girls that were positive and significant before, estimates in Table 18 show that this is no longer the case when these controls are added in the second stage, underlining the importance of the role they play in explaining the Christian advantage today. Consistent with the discussion in Section III, results in Tables 15-18 shed light on some of the (measurable) mechanisms that underlie the HFA advantage evident among Christian infant children in India today, especially girls.

\section{Why Christian girls and less so Christian boys?}

The tables above make clear that while infant boys have coefficients that are about the same size in magnitude as infant girls, impacts are measured with significance mostly for the latter group. There is now a substantial literature in economics that notes differences in the effects of interventions by gender where health investments are found to primarily increase the schooling of women but the returns to productivity for men, and schooling interventions are found to mainly increase the labor market returns of women (Bobonis et al. 2006, Maluccio et al. 2009, Field et al. 2009), with much of the differences attributable to the brawn versus skill-based nature of the economy (Pitt et al. 2012). In the context of this study, the coming of Christianity to India was a natural experiment that was both a health and schooling investment in lower-caste Hindus primarily which, as shown above, increased the health potential of girls 
as evident in their HFA z-score. Since height is correlated with cognitive ability (Case and Paxson 2008) and given the brawn-based nature of the colonial Indian economy, it is possible that over time, women and girls would have had relatively higher growth rates of cognitive skills with respect to the previous generation of women and girls, but also in relation to the cognitive growth rates of men and boys in the same generation. We see some evidence for this from the 1901 census since Christian males and females had literacy rates that far exceeded those of the Hindu and Muslim populations (Figures 2A and 2B) and growth rates in female literacy that exceeded growth rates in male literacy at least as far back as 1881 (Figures 3A and 3B), also when the population is restricted to those who are 15 years or older (Figure 3C). Could mothers with higher cognitive ability (compared to previous generations) bequeath relatively the same size in HFA advantage to their sons and daughters, but the effect is measured more precisely for daughters in comparison to sons? There is evidence from Silventoinen et al. (2003) that this might be the case. If you consider determinants of height, Case and Paxson (2008) argue that about eighty percent is genetic (heritability) whereas about twenty percent is the environment (uterine environment, nutritional status and the disease environment). Genetics change slowly but the environment may be shaped more rapidly and Silventoinen et al. (2003) indicates that the latter is more important for determining height in female populations. In colonial India, the "signal" would have been the strongest in terms of changing and reinforcing the environment that lower-caste mothers faced upon conversion to Christianity; this may thus lead to the reduced "noise" that we document in the child height measures for Christian girls today. E. Why do these effects not last beyond infancy?

The results of the paper also make clear that advantages documented for Christian children do not persist beyond infancy in many cases. ${ }^{7}$ This is unlikely to be due to selection as has been noted before with the same NFHS data for India (Alderman et al. 2011, Brainerd and Menon 2015). That these effects are strongest in infancy suggests that they arise from characteristics of mother's health. Beyond infancy however, children are often more mobile and thus susceptible to infections, there are substantial dietary changes, and depending on cultural and religious backgrounds, they may lack certain important inputs for

\footnotetext{
${ }^{7}$ This is also true for upper-caste Hindu and Muslim children in some cases.
} 
growth (comparatively less of a factor for Christian children however given their socio-economic status).

The overall environment becomes more important in terms of investments in child's human capital. Although we control for all the factors that we can, the NFHS data are not refined enough in terms of dietary intakes and timing of changes for us to check such things explicitly. Given length of history, perhaps aspects of conversion to Christianity from over two hundred years ago have explanatory power only with respect to infants in our sample, or perhaps HFA is measured with less error in younger age groups. Future research with access to richer data is called for to answer this question comprehensively.

\section{Conclusion and implications for policy}

In a country marked by relatively high rates of child malnutrition and cultural phenomena such as son preference, Christian children appear to do relatively well. In particular, Christian infant girls in all states and especially those with relatively large Christian populations score substantially higher in terms of HFA z-scores than lower-caste Hindu children. Although this in of itself may not be surprising, Christian children, in many instances, are found to do better in terms of this measure even with respect to upper-caste Hindu and Muslim children net of a whole set of controls for child, mother, father, household and state characteristics. Although the Muslim advantage in infancy (with respect to lower-caste Hindus) and its later reversal in India has been documented, to the best of our knowledge, this is the first study that shows that Christian children, especially girls, fare even better at a critical stage in child development. Using historical records from British India and earlier, we demonstrate that these patterns are plausibly tied to the legacy of the advent and spread of Christianity, where Christian teachings that emphasized egalitarian principles and that stressed the importance of basic health, hygiene and sanitation, are found to have long-term implications on child health today. Our results are robust to a wide series of specification checks and we offer an explanation for why Christian girls in particular benefitted. In terms of policy, our results underscore the importance of health and schooling investments in women as the returns to building their human capital clearly accrues over generations. Finally, in the spirit of Case and Paxson (2008), in on-going work, we seek to link this Christian advantage and our colonial data to present-day occupational choice, wages, and the (residual) wage gap between men and women in India today. 


\section{References}

Alderman, Harold, Michael Lokshin and Sergiy Radyakin (2011), "Tall Claims: Mortality Selection and the Height of Children in India," Economics and Human Biology 9: 393-406.

Alesina, Alberto, Giuliano, Paola, and Nathan Nunn (2013), "On the Origins of Gender Roles: Women and the Plough,” The Quarterly Journal of Economics 128: 469-530.

Almond, Douglas and Bhashkar Mazumder (2011), "Health Capital and the Prenatal Environment: The Effect of Ramadan Observance During Pregnancy," American Economic Journal: Applied Economics 3: 56-85.

Barcellos, Silvia Helena, Leandro S. Carvalho and Adriana Lleras-Muney (2014), "Child Gender and Parental Investments in India: Are Boys and Girls Treated Differently?" American Economic Journal: Applied Economics 6(1): 157-189.

Barro, Robert, and Rachel McCleary (2005), “Which Countries Have State Religions?” The Quarterly Journal of Economics 120: 1331-1370.

Behrman, Jere and Mark Rosenzweig (2004), "Returns to Birthweight," Review of Economics and Statistics 86(2): 586-601.

Behrman, Jere (2009), "Early Life Nutrition and Subsequent Education, Health, Wage, and Intergenerational Effects," in Health and Growth, edited by Michael Spence and Maureen Lewis. Washington D.C.: The World Bank.

Bhalotra, Sonia, Christine Valente, and Arthur van Soest (2010), "The Puzzle of Muslim Advantage in Child Survival in India," Journal of Health Economics 29: 191-204.

Bharadwaj, Prashant and Leah K. Lakdawala (2012), "Discrimination Begins in the Womb: Evidence of Sex-Selective Prenatal Investments,” The Journal of Human Resources 48(10: 71-113.

Bobonis, Gustavo J., Miguel, Edward, and Charu Puri-Sharma (2006), “Anemia and School Participation," Journal of Human Resources 41(4): 692-721.

Brainerd, Elizabeth and Nidhiya Menon (2014), "Seasonal Effects of Water Quality: The Hidden Costs of the Green Revolution to Infant and Child Health in India," Journal of Development Economics 107: 49-64.

Brainerd, Elizabeth and Nidhiya Menon (2015), "Religion and Health in Early Childhood: Evidence from South Asia," Population and Development Review, forthcoming.

Cage, J, and V. Rueda (2013), "The Long Term Effects of the Printing Press in Sub-Saharan Africa," PSE Working Papers halshs-00844446, HAL.

Case, Anne and Christina Paxson (2008), "Stature and Status: Height, Ability and Labor Market Outcomes," Journal of Political Economy 116(5): 499-532.

Calvi, Rossella and Federico G. Mantovanelli (2014), "Long-Term Effects of Access to Health Care: Medical Missions in Colonial India," Boston College, Mimeo. 
Cunha, Flavio and James Heckman (2007), “The Technology of Skill Formation,” American Economic Review 97(2): 31-47.

Currie, Janet and Tom Vogl (2013), "Early-Life Health and Adult Circumstance in Developing Countries," Annual Review of Economics 5:1-36.

Davis, Lee (2008), Natural Disasters, Checkmark Books.

Deaton, Angus and Jean Drèze (2009), "Food and Nutrition in India: Facts and Interpretations," Economic \& Political Weekly 44(7): 42-65.

Eliot, John (1900), Handbook of Cyclonic Storms in the Bay of Bengal V1: For the Use of Sailors, Kessinger Publishing, LLC.

Field, Erica, Robles, Omar, and Maximo Torero (2009), "Iodine Deficiency and Schooling Attainment in Tanzania, “ American Economic Journal: Applied Economics 1(4): 140-169.

Jayachandran, Seema (2009), “Air Quality and Early-Life Mortality: Evidence from Indonesia’s Wildfires," Journal of Human Resources 44(4): 916-954.

Jayachandran, Seema and Ilyana Kuziemko (2011), "Why Do Mothers Breastfeed Girls Less Than Boys? Evidence and Implications for Child Health in India," The Quarterly Journal of Economics 126: $1485-1538$.

Jayachandran, Seema and Rohini Pande (2014), “Why Are Indian Children So Short?”, Mimeo.

Kent, Eliza F. (2004), Converting Women: Gender and Protestant Christianity in Colonial South India, New York: Oxford University Press.

Kooiman, Dick (1988), "Change of Religion as a Way to Survival” in Religion and Development: Towards an Integrated Approach, Amsterdam: Free University Press.

McAlpin, Michelle Burge (1983), Subject to Famine: Food Crisis and Economic Change in Western India, 1860-1920, New York: Princeton University Press.

Maluccio, John A., Hoddinott, John, Behrman, Jere R., Martorell, Reynaldo, Quisumbing, Agnes, and Aryeh D. Stein (2009), "The Impact of Improving Nutrition in Early Childhood on Education among Guatemalan Adults,” Economic Journal 119 (537): 734-763.

Mantovanelli, Federico (2014), “The Protestant Legacy: Missions and Literacy in India,” Boston College, Mimeo.

Meng, Xin, Xiaodong Gong, and Youjuan Wang (2009), "Impact of Income Growth and Economic Reform on Nutrition Availability in Urban China: 1986-2000," Economic Development and Cultural Change 57 (2): 261-295.

Nunn, Nathan (2009), “The Importance of History for Economic Development," Annual Review of Economics 1: 65-92.

Nunn, Nathan (2010), "Religious Conversion in Colonial Africa," American Economic Review 100: 147152.

Pickett, Jarrell Waskom (1933), Christian Mass Movements in India, A Study With Recommendations, National Christian Council of India. 
Pitt, Mark M., Rosenzweig, Mark R. and Mohammad Nazmul Hassan (2012), "Human Capital Investment and the Gender Division of Labor in a Brawn-Based Economy," American Economic Review 102(7): 3531-3560.

Silventoinen, Karri, Sammalisto, Sampo, Perola, Markus, Boomsma, Dorret I., Cornes, Belinda K., Davis, Chayna, Dunkel, Leo, de Lange, Marlies, Harris, Jennifer R., Hjelmborg, Jacob V.B., Luciano, Michelle, Martin, Nicholas G., Mortensen, Jakob, Nistico, Lorenza, Pedersen, Nancy L., Skytthe, Axel, Spector, Tim D., Stazi, Maria Antonietta, Willemsen, Gonneke, and Jaakko Kaprio (2003), "Heritability of Adult Body Height: A Comparative Study of Twin Cohorts in Eight Countries," Twin Research 6(5): 399-408.

van Ewijk, Reyn (2011), "Long-term Health Effects on the Next Generation of Ramadan Fasting During Pregnancy," Journal of Health Economics 30: 1246-1260. 
Figure 1: Height-for-age by religion and child's gender
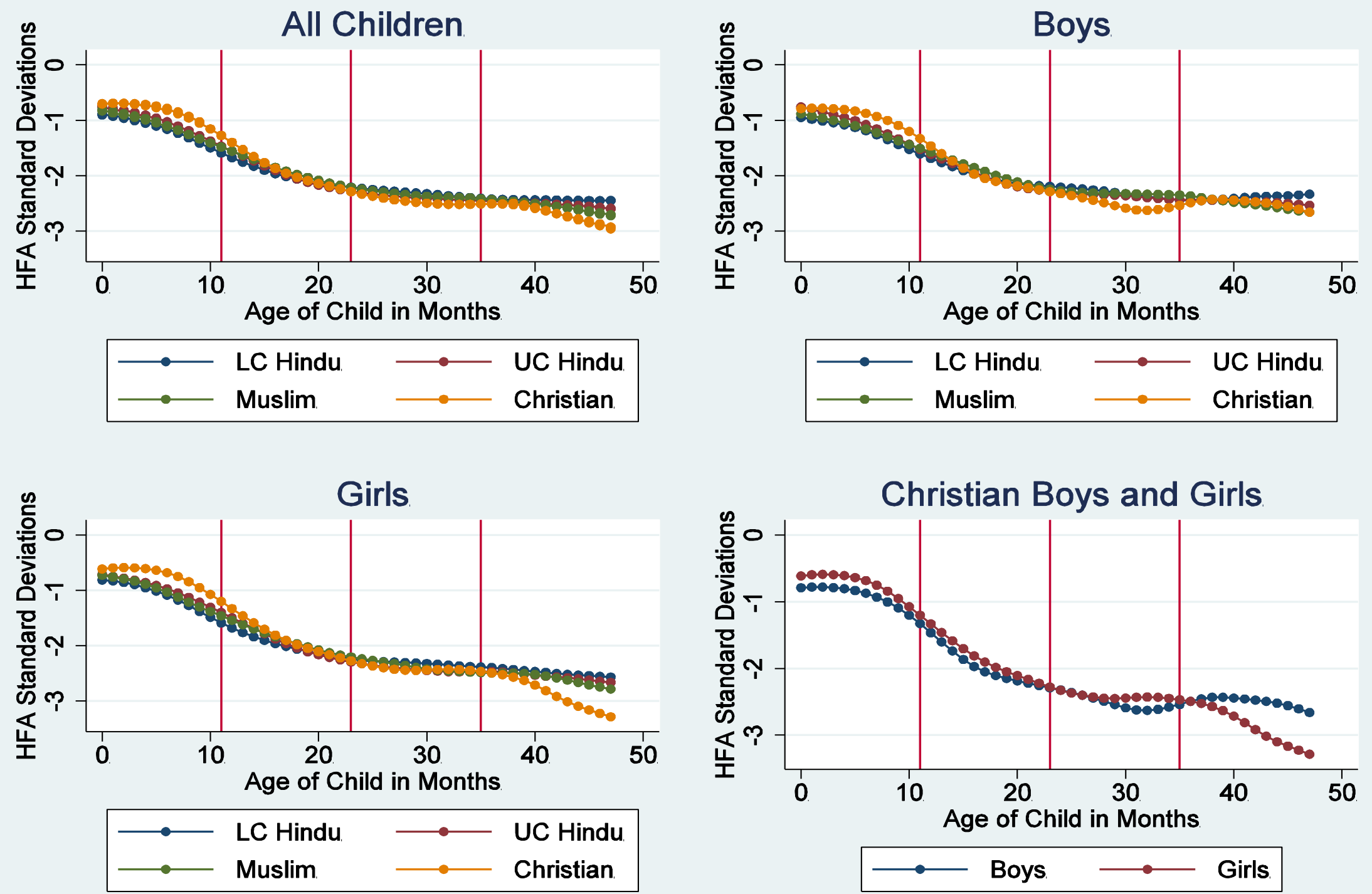
Figure 2A: Number of literate males per 1000 by religion

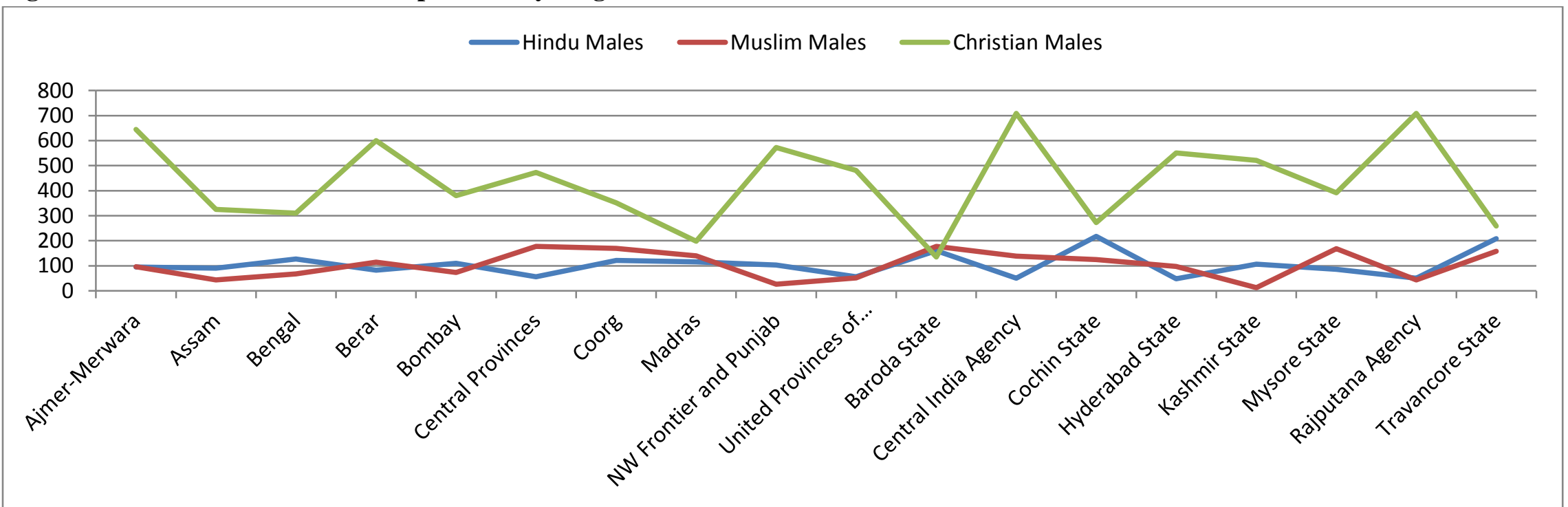

\section{Figure 2B: Number of literate females per 1000 by religion}

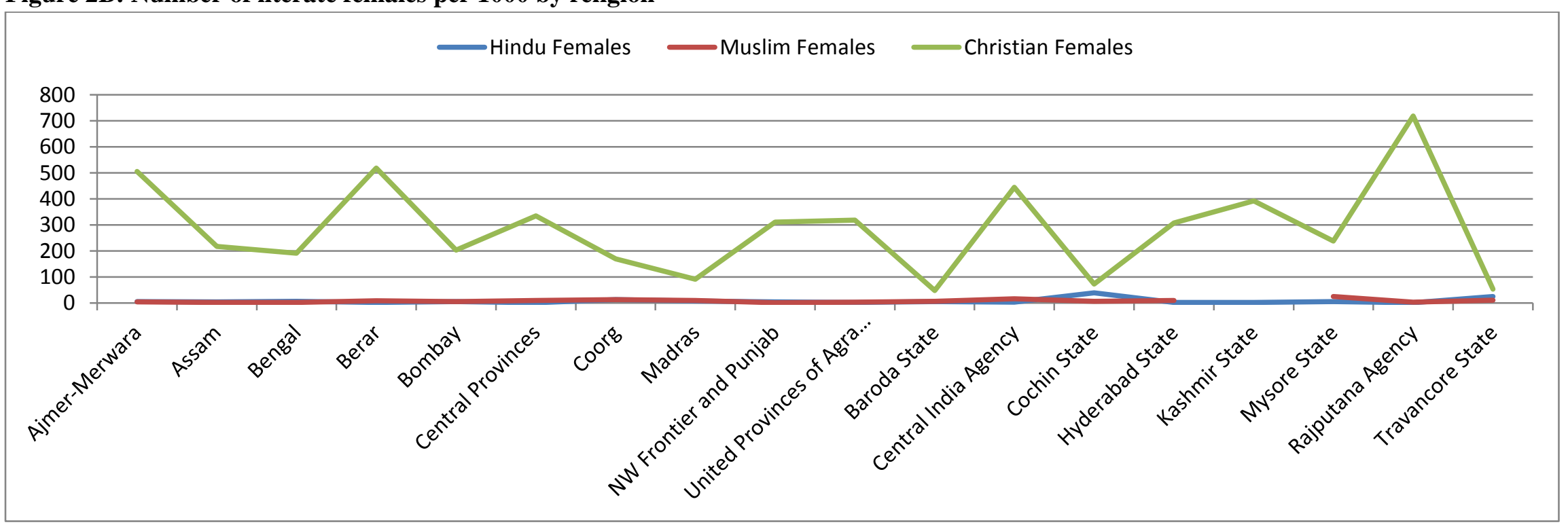


Figure 3A: Comparison of growth rates in literacy by gender: 1881-1891

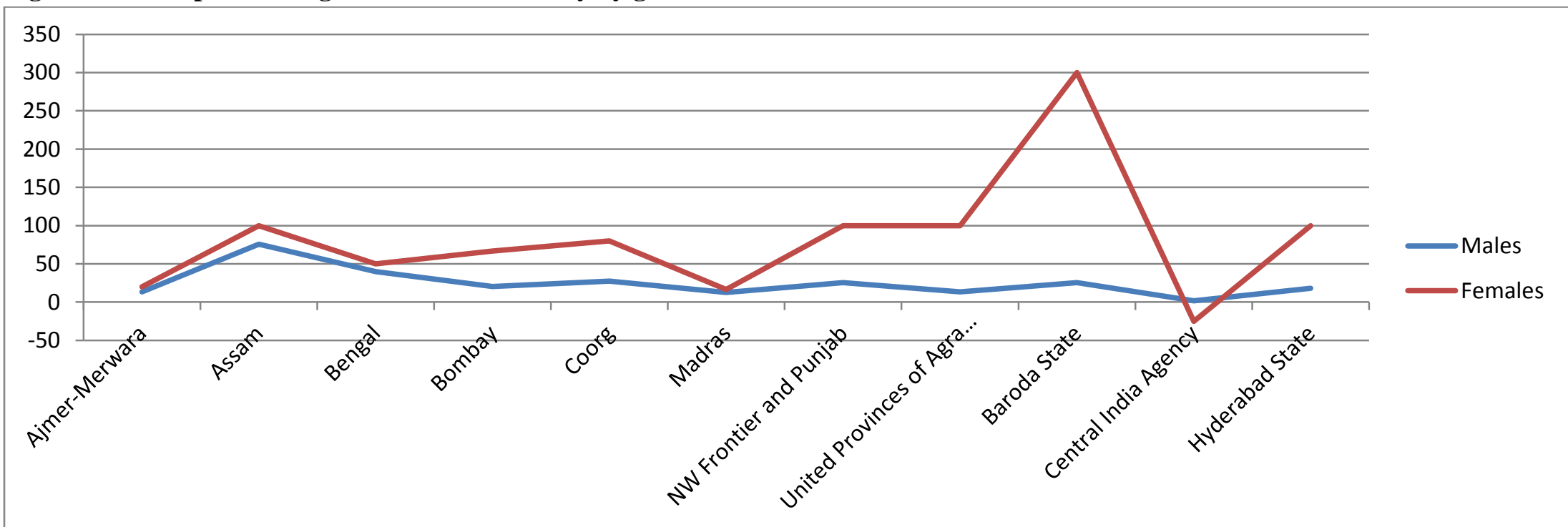

\section{Figure 3B: Comparison of growth rates in literacy by gender: 1891-1901}

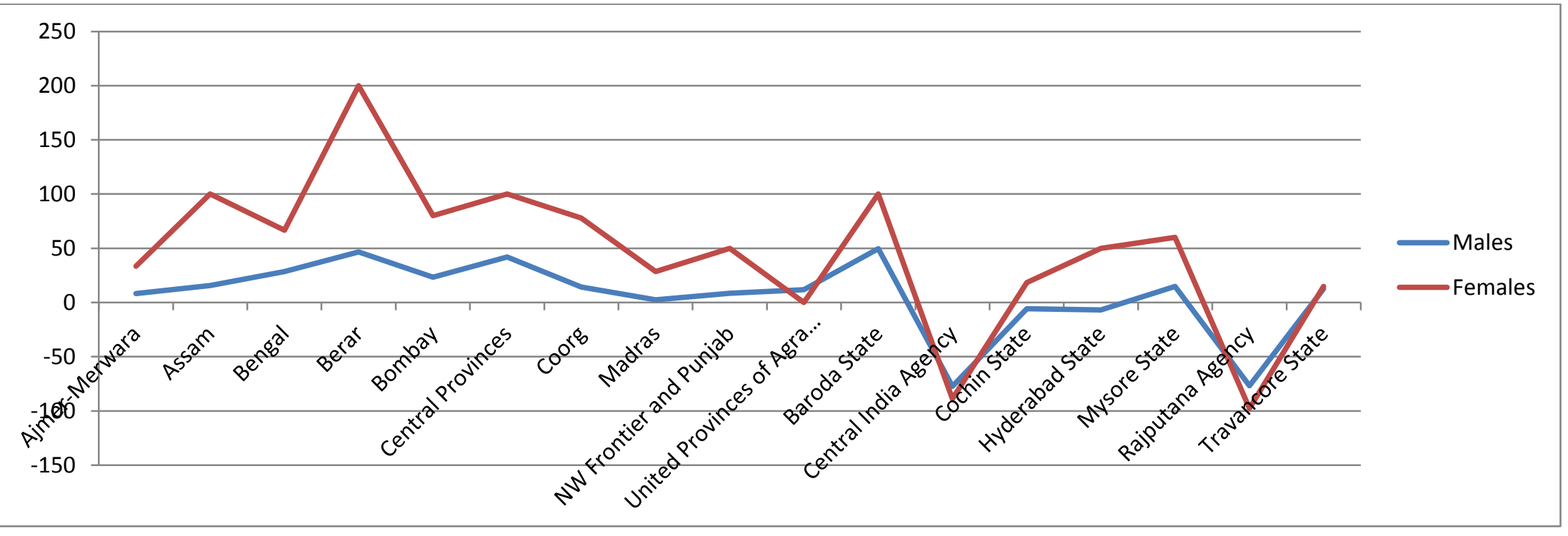


Figure 3C: Comparison of growth rates in literacy for those over 15 years by gender: 1891-1901

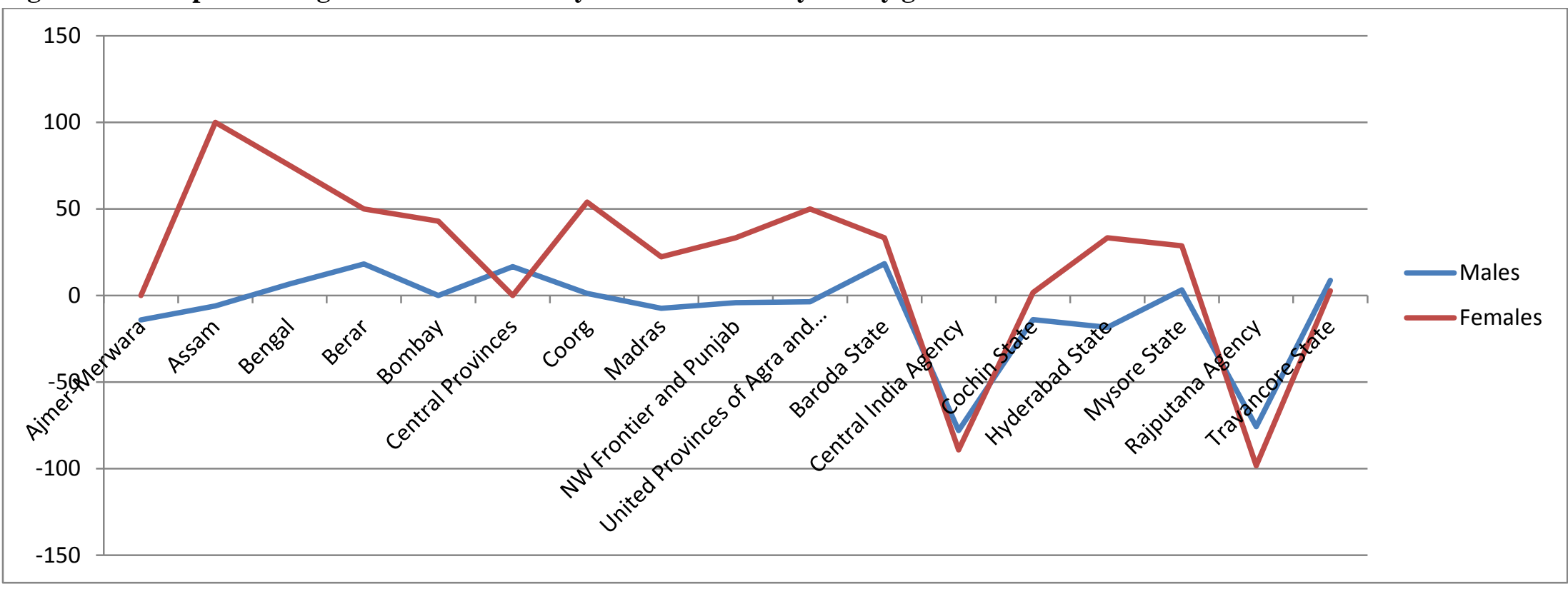


Map 1: Map of Protestant Missions in India as of 1910, Southern Section

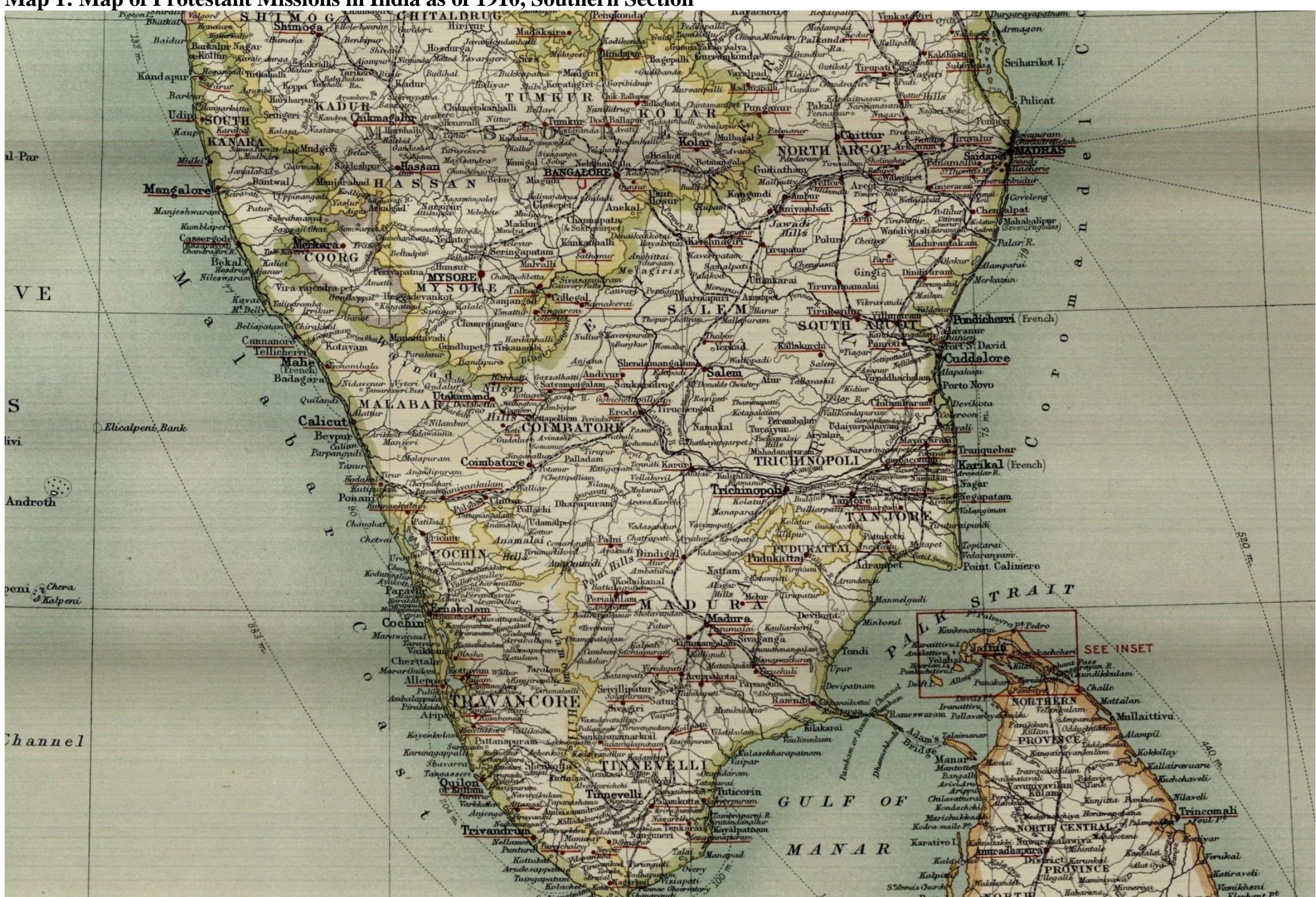

Source: Statistical Atlas of Christian Missions, Plate 13. 


\section{Map 2: Locations of Catholic Missions in Southern India as of 1911}

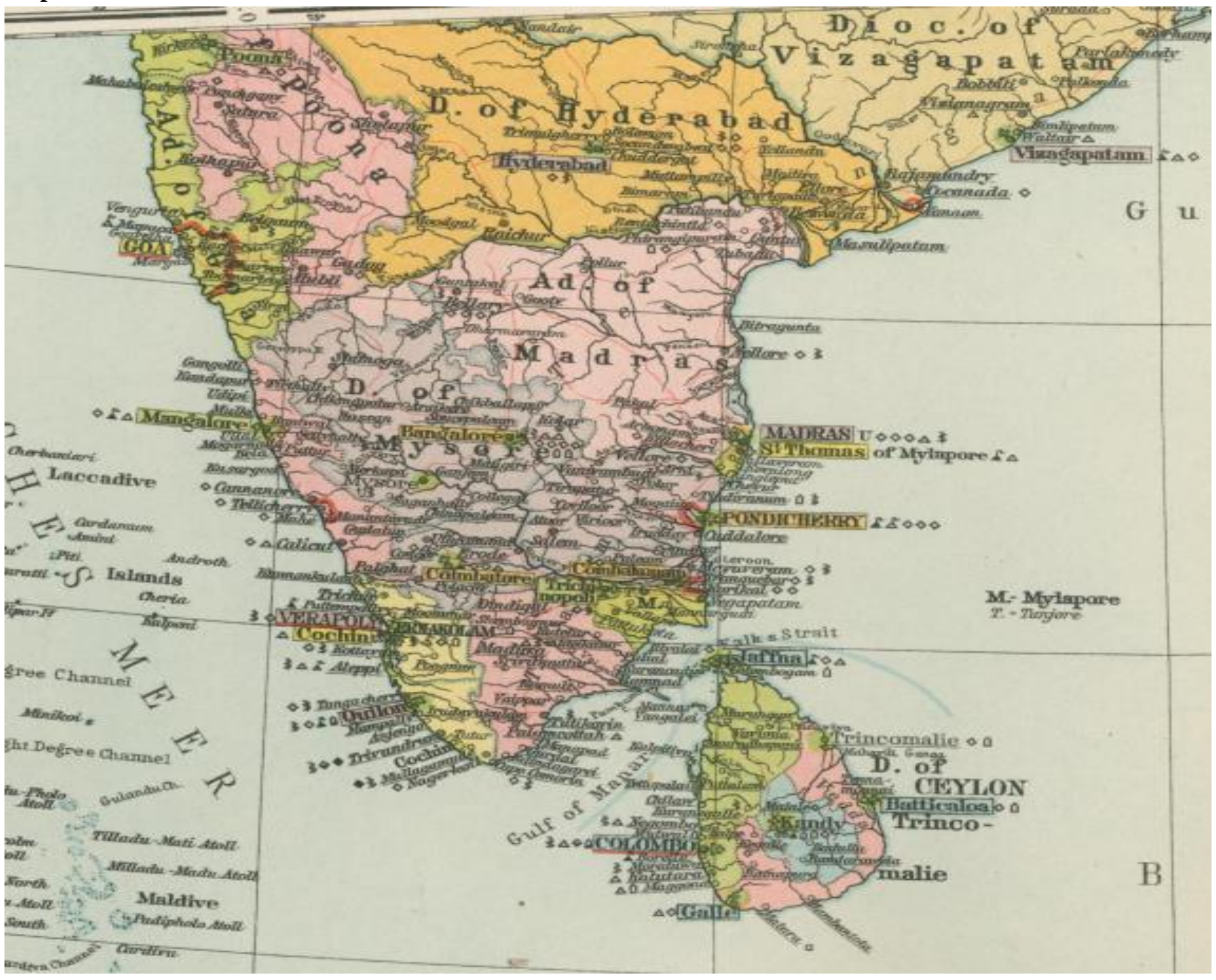

Source: Atlas Heirarchichus, Asia Sheet I. 
Table 1: Summary statistics by religion

\begin{tabular}{|c|c|c|c|c|}
\hline Variables & $\begin{array}{c}\text { Lower-caste } \\
\text { Hindu }\end{array}$ & $\begin{array}{c}\text { Upper-caste } \\
\text { Hindu }\end{array}$ & Muslim & Christian \\
\hline \multicolumn{5}{|l|}{ Child-specific } \\
\hline Height-for-age & $\begin{array}{l}-2.325 \\
(1.822)\end{array}$ & $\begin{array}{l}-2.085 \\
(1.782)\end{array}$ & $\begin{array}{l}-2.262 \\
(1.794)\end{array}$ & $\begin{array}{l}-1.558 \\
(1.755)\end{array}$ \\
\hline Age in months & $\begin{array}{c}19.786 \\
(12.192)\end{array}$ & $\begin{array}{c}29.572 \\
(12.448)\end{array}$ & $\begin{array}{c}20.434 \\
(12.468)\end{array}$ & $\begin{array}{c}20.053 \\
(11.799)\end{array}$ \\
\hline Order of birth & $\begin{array}{l}3.170 \\
(2.001)\end{array}$ & $\begin{array}{c}2.829 \\
(1.871)\end{array}$ & $\begin{array}{c}3.540 \\
(2.312)\end{array}$ & $\begin{array}{c}2.500 \\
(1.716)\end{array}$ \\
\hline $\begin{array}{l}\text { Dummy for male } \\
\text { child }\end{array}$ & $\begin{array}{l}.508 \\
(.500)\end{array}$ & $\begin{array}{l}.515 \\
(.500)\end{array}$ & $\begin{array}{l}.504 \\
(.500)\end{array}$ & $\begin{array}{l}.514 \\
(.500)\end{array}$ \\
\hline $\begin{array}{l}\text { Dummy for child } \\
\text { was nursed }\end{array}$ & $\begin{array}{l}.932 \\
(.252)\end{array}$ & $\begin{array}{l}.934 \\
(.248)\end{array}$ & $\begin{array}{c}.922 \\
(.268)\end{array}$ & $\begin{array}{c}.884 \\
(.320)\end{array}$ \\
\hline $\begin{array}{l}\text { Dummy for child had } \\
\text { diarrhea in last two weeks }\end{array}$ & $\begin{array}{l}.167 \\
(.373)\end{array}$ & $\begin{array}{l}.145 \\
(.352)\end{array}$ & $\begin{array}{l}.152 \\
(.359)\end{array}$ & $\begin{array}{l}.139 \\
(.346)\end{array}$ \\
\hline $\begin{array}{l}\text { Dummy for child had } \\
\text { cough in last two weeks }\end{array}$ & $\begin{array}{l}.296 \\
(.456)\end{array}$ & $\begin{array}{l}.269 \\
(.444)\end{array}$ & $\begin{array}{l}.298 \\
(.457)\end{array}$ & $\begin{array}{l}.332 \\
(.471)\end{array}$ \\
\hline $\begin{array}{l}\text { Child was exposed } \\
\text { to Ramadan in utero }\end{array}$ & & & $\begin{array}{l}.181 \\
(.385)\end{array}$ & \\
\hline \multicolumn{5}{|l|}{ Woman-specific } \\
\hline $\begin{array}{l}\text { Dummy for had prenatal } \\
\text { or antenatal doctor check }\end{array}$ & $\begin{array}{c}.341 \\
(.474)\end{array}$ & $\begin{array}{l}.478 \\
(.500)\end{array}$ & $\begin{array}{c}.465 \\
(.499)\end{array}$ & $\begin{array}{l}.705 \\
(.456)\end{array}$ \\
\hline Age of woman & $\begin{array}{l}25.552 \\
(5.672)\end{array}$ & $\begin{array}{l}25.874 \\
(5.561)\end{array}$ & $\begin{array}{l}26.638 \\
(6.254)\end{array}$ & $\begin{array}{l}26.947 \\
(5.367)\end{array}$ \\
\hline Age at first birth & $\begin{array}{l}18.239 \\
(2.948)\end{array}$ & $\begin{array}{l}19.223 \\
(3.303)\end{array}$ & $\begin{array}{l}18.432 \\
(3.070)\end{array}$ & $\begin{array}{l}21.285 \\
(4.043)\end{array}$ \\
\hline Age at first marriage & $\begin{array}{l}16.200 \\
(2.667)\end{array}$ & $\begin{array}{l}17.119 \\
(3.083)\end{array}$ & $\begin{array}{l}16.532 \\
(2.771)\end{array}$ & $\begin{array}{l}19.957 \\
(3.912)\end{array}$ \\
\hline $\begin{array}{l}\text { Woman has had miscarriage, } \\
\text { stillbirth or abortion }\end{array}$ & $\begin{array}{l}.168 \\
(.374)\end{array}$ & $\begin{array}{l}.173 \\
(.378)\end{array}$ & $\begin{array}{l}.196 \\
(.397)\end{array}$ & $\begin{array}{l}.156 \\
(.363)\end{array}$ \\
\hline $\begin{array}{l}\text { Dummy for woman } \\
\text { is literate }\end{array}$ & $\begin{array}{l}.126 \\
(.331)\end{array}$ & $\begin{array}{l}.308 \\
(.462)\end{array}$ & $\begin{array}{l}.247 \\
(.431)\end{array}$ & $\begin{array}{l}.563 \\
(.496)\end{array}$ \\
\hline Woman has no education & $\begin{array}{l}.751 \\
(.433)\end{array}$ & $\begin{array}{l}.525 \\
(.499)\end{array}$ & $\begin{array}{c}.629 \\
(.483)\end{array}$ & $\begin{array}{l}.252 \\
(.434)\end{array}$ \\
\hline $\begin{array}{l}\text { Woman has some or all } \\
\text { primary school }\end{array}$ & $\begin{array}{l}.117 \\
(.322)\end{array}$ & $\begin{array}{l}.151 \\
(.358)\end{array}$ & $\begin{array}{l}.163 \\
(.369)\end{array}$ & $\begin{array}{l}.195 \\
(.396)\end{array}$ \\
\hline $\begin{array}{l}\text { Woman has some secondary } \\
\text { school }\end{array}$ & $\begin{array}{l}.098 \\
.(298)\end{array}$ & $\begin{array}{l}.208 \\
(.406)\end{array}$ & $\begin{array}{l}.155 \\
(.362)\end{array}$ & $\begin{array}{l}.322 \\
(.467)\end{array}$ \\
\hline $\begin{array}{l}\text { Woman has completed } \\
\text { secondary school or higher }\end{array}$ & $\begin{array}{l}.034 \\
(.182)\end{array}$ & $\begin{array}{l}.116 \\
(.320)\end{array}$ & $\begin{array}{l}.053 \\
(.224)\end{array}$ & $\begin{array}{l}.231 \\
(.421)\end{array}$ \\
\hline Child was large at birth & $\begin{array}{l}.141 \\
(.348)\end{array}$ & $\begin{array}{l}.142 \\
(.329)\end{array}$ & $\begin{array}{l}.145 \\
(.352)\end{array}$ & $\begin{array}{l}.206 \\
(.404)\end{array}$ \\
\hline Child was average at birth & $\begin{array}{l}.621 \\
(.485)\end{array}$ & $\begin{array}{l}.648 \\
(.478)\end{array}$ & $\begin{array}{l}.658 \\
(.474)\end{array}$ & $\begin{array}{l}.599 \\
(.490)\end{array}$ \\
\hline
\end{tabular}




\begin{tabular}{|c|c|c|c|c|}
\hline Child was small at birth & $\begin{array}{c}.238 \\
(.426)\end{array}$ & $\begin{array}{c}.211 \\
(.408)\end{array}$ & $\begin{array}{c}.197 \\
(.398)\end{array}$ & $\begin{array}{c}.196 \\
(.397)\end{array}$ \\
\hline \multirow[t]{2}{*}{ Woman is currently working } & .409 & .271 & .146 & .331 \\
\hline & $(.492)$ & $(.445)$ & $(.354)$ & $(.471)$ \\
\hline Woman works in farming, & .472 & .448 & .459 & .478 \\
\hline fishing, hunting or logging & $(.499)$ & $(.497)$ & $(.498)$ & $(.500)$ \\
\hline Number of children five & 1.981 & 2.035 & 2.197 & 1.757 \\
\hline years old and under & $(1.017)$ & $(1.190)$ & $(1.209)$ & $(.791)$ \\
\hline Number of years since first & 9.166 & 8.584 & 9.968 & 6.814 \\
\hline marriage & $(5.852)$ & $(5.772)$ & $(6.475)$ & $(4.853)$ \\
\hline Woman watches cinema at & .066 & .106 & .066 & .137 \\
\hline least once a month & $(.249)$ & $(.307)$ & $(.247)$ & $(.344)$ \\
\hline Woman listens to radio every & .255 & .386 & .314 & .519 \\
\hline week & $(.436)$ & $(.487)$ & $(.464)$ & $(.500)$ \\
\hline \multirow[t]{2}{*}{ Husband's age } & 31.496 & 31.549 & 33.245 & 32.516 \\
\hline & $(7.784)$ & $(6.923)$ & $(7.835)$ & $(6.952)$ \\
\hline Dummy for husband has no & .211 & .203 & .250 & .207 \\
\hline education & $(.408)$ & $(.402)$ & $(.433)$ & $(.405)$ \\
\hline Dummy for husband has some or & .209 & .287 & .207 & .328 \\
\hline all primary school & $(.407)$ & $(.452)$ & $(.405)$ & $(.469)$ \\
\hline Dummy for husband has completed & .139 & .268 & .136 & .281 \\
\hline secondary school or higher & $(.346)$ & $(.443)$ & $(.343)$ & $(.450)$ \\
\hline Dummy for husband works & .976 & .972 & .975 & .979 \\
\hline outside the home & $(.153)$ & $(.165)$ & $(.157)$ & $(.143)$ \\
\hline Husband works in farming, & .544 & .436 & .301 & .405 \\
\hline fishing, hunting or logging & $(.498)$ & $(.496)$ & $(.459)$ & $(.491)$ \\
\hline \multicolumn{5}{|l|}{ Household-specific } \\
\hline \multirow[t]{2}{*}{ Rural household } & .849 & .754 & .675 & .693 \\
\hline & $(.358)$ & $(.431)$ & $(.469)$ & $(.461)$ \\
\hline \multirow[t]{2}{*}{ Age of household head } & 40.698 & 43.509 & 42.483 & 41.067 \\
\hline & $(14.704)$ & $(15.474)$ & $(14.635)$ & $(14.492)$ \\
\hline Dummy for household has male & .951 & .943 & .928 & .912 \\
\hline head & $(.215)$ & $(.232)$ & $(.259)$ & $(.283)$ \\
\hline Dummy for household religion is & 1.000 & & & \\
\hline Hinduism (lower-caste for India) & $(.000)$ & & & \\
\hline Dummy for household religion is & & 1.000 & & \\
\hline Hinduism (upper-caste for India) & & $(.000)$ & & \\
\hline Dummy for household religion is & & & 1.000 & \\
\hline Islam & & & $(.000)$ & \\
\hline Dummy for household religion is & & & & 1.000 \\
\hline Christianity & & & & $(.000)$ \\
\hline Dummy for household owns a car & .001 & .013 & .005 & .024 \\
\hline or a refrigerator (assets) & $(.025)$ & $(.115)$ & $(.068)$ & $(.153)$ \\
\hline Dummy for household owns a car & .003 & .018 & .011 & .026 \\
\hline only & $(.050)$ & $(.133)$ & $(.104)$ & $(.161)$ \\
\hline
\end{tabular}




\begin{tabular}{lcccc}
\hline Dummy for household owns a & .044 & .140 & .083 & .150 \\
motorcycle & $(.205)$ & $(.347)$ & $(.276)$ & $(.357)$ \\
Dummy for household has & .447 & .617 & .531 & .700 \\
electricity & $(.497)$ & $(.486)$ & $(.499)$ & $(.459)$ \\
Source of drinking water: piped & .257 & .366 & .354 & .464 \\
water & $. .437)$ & $(.482)$ & $(.478)$ & $(.499)$ \\
Source of drinking water: ground & .468 & .411 & .477 & .126 \\
water & $(.499)$ & $(.492)$ & $(.500)$ & $(.332)$ \\
Source of drinking water: well & .236 & .195 & .143 & .286 \\
water & $(.425)$ & $(.396)$ & $(.350)$ & $(.452)$ \\
Source of drinking water: surface & .032 & .021 & .019 & .119 \\
water & $(.176)$ & $(.142)$ & $(.138)$ & $(.324)$ \\
Source of drinking water: rainwater & .007 & .007 & .007 & .005 \\
tanker truck, other & $. .083)$ & $(.084)$ & $(.083)$ & $(.069)$ \\
Toilet facility is: flush toilet & .097 & .228 & .262 & .287 \\
& $(.296)$ & $(.419)$ & $(.440)$ & $(.452)$ \\
Toilet facility is: pit toilet/latrine & .053 & .088 & .232 & .282 \\
& $(.224)$ & $(.283)$ & $(.422)$ & $(.450)$ \\
Toilet facility is: no facility/bush/ & .850 & .683 & .504 & .432 \\
field & $(.358)$ & $(.465)$ & $(.500)$ & $(.495)$ \\
Toilet facility is: other & .001 & .001 & .002 & .000 \\
Years lived in place of residence & $(.028)$ & $(.037)$ & $(.047)$ & $(.000)$ \\
& 12.163 & 11.548 & 14.006 & 19.737 \\
\end{tabular}

Notes: Weighted to national levels by weights provided by the DHS. Standard deviations in parentheses.

Total number of observations is 44,116 of which 34,360 (77.89 percent) are Hindus, 6,352 (14.40 percent) are Muslim, and 3,404 (7.72 percent) are Christian. Table reports statistics at the unique level for children, women, and households.

Table 1: Summary statistics for states

\begin{tabular}{l|cc}
\hline Variables & All States & States with Christian \\
Per capita GDP & 2234.947 & 2607.923 \\
Dummy for Christian majority state & $(1033.770)$ & $(971.253)$ \\
& .233 & 1.000 \\
Wheat crop area & $(.427)$ & $(.000)$ \\
Summer rice crop area & .092 & .008 \\
& $(.168)$ & $. .011)$ \\
Winter rice crop area & .010 & .012 \\
& $(.022)$ & $(.014)$ \\
Autumn rice crop area & .034 & .021 \\
& $(.075)$ & $. .036)$ \\
& .018 & .030
\end{tabular}


Rainfall in millimeters $\left(\times 10^{-2}\right)$

Consumer price index for agricultural laborers (base: 1986-1987=100)

Per capita calories (in Kilo calories per day)

Per capita protein intake (in grams per day)

Per capita fat intake (in grams per day)

Number of malaria/TB deaths normalized by state population

Infant mortality rate (per 1000 live births)

Gini coefficient of distribution of consumption

Public subsidies (approved normal central assistance)

Average air temperature (in degrees Celsius)

Number of cities at or above 1500 feet in district as of 1893

Number of cities on railway lines in district as of 1893

Number of cities on navigable canals in district as of 1893

Number of Protestant missions in district as of 1910

Difference between year of birth and earliest year of establishment of Protestant mission Number of Protestant missions*difference b/w birth year and earliest year of Protestant est. Number of Catholic missions in district as of 1910

Difference between year of birth and earliest year of establishment of Catholic mission Number of Catholic missions*difference b/w birth year and earliest year of Catholic est. Total number of wars mission establishing countries were engaged in as of 1910

\begin{tabular}{|c|c|}
\hline 1.175 & 1.356 \\
\hline$(.568)$ & $(.477)$ \\
\hline 141.374 & 237.500 \\
\hline$(231.525)$ & $(85.022)$ \\
\hline 2113.821 & 1993.788 \\
\hline (160.066) & $(48.157)$ \\
\hline 58.069 & 53.256 \\
\hline (9.186) & $(2.952)$ \\
\hline 37.753 & 38.016 \\
\hline (13.878) & $(4.755)$ \\
\hline .002 & .001 \\
\hline$(.003)$ & $(.001)$ \\
\hline 64.933 & 47.261 \\
\hline (21.952) & (19.661) \\
\hline .274 & .316 \\
\hline$(.038)$ & $(.017)$ \\
\hline 1791.121 & 2949.090 \\
\hline (1761.483) & $(2473.211)$ \\
\hline 25.122 & 26.919 \\
\hline (1.879) & $(.966)$ \\
\hline 6.797 & 6.764 \\
\hline (17.063) & $(6.003)$ \\
\hline 2.405 & 2.887 \\
\hline (3.353) & $(1.751)$ \\
\hline 1.497 & .561 \\
\hline (1.970) & (1.068) \\
\hline 3.046 & 3.985 \\
\hline (2.039) & $(3.485)$ \\
\hline 141.528 & 136.867 \\
\hline (56.905) & $(80.445)$ \\
\hline 511.615 & 827.704 \\
\hline (557.433) & (1054.449) \\
\hline .843 & 2.508 \\
\hline (1.193) & (1.505) \\
\hline 101.948 & 276.339 \\
\hline (134.835) & (129.279) \\
\hline 248.461 & 858.202 \\
\hline (428.624) & $(540.757)$ \\
\hline 5.949 & 10.629 \\
\hline$(5.391)$ & $(8.218)$ \\
\hline
\end{tabular}


Number of times there were intense famines as of 1910

Total length of time famine lasted in years

Total number of cyclones as of 1910

Total number of earthquakes as of 1910

Ratio of deaths from injuries (suicides, wounding, Accidents, snake-bites) per 1000 people

Ratio of deaths from cholera per 1000 people

Ratio of deaths from fever per 1000 people

Average number of people affected in the famine

Average population per square mile (1901 census)

Average population per square mile in cities (1901 census)

Proportion supported by industry per 1000 of population (1901 census)

Number of females afflicted by blindness per 1000 of population (1901 census)

Number of literate males per 1000 of population (1901 census)

Number of literate females per 1000 of population (1901 census)

Number per 10,000 of population who were immigrants where enumerated (1901 census) Number of hospitals

Number of pharmacies

Number of print shops

Number of native/indigenous Laien brothers

Number of native/indigenous Schwestern sisters

\begin{tabular}{|c|c|}
\hline .020 & .030 \\
\hline$(.048)$ & $(.064)$ \\
\hline .204 & .257 \\
\hline$(.269)$ & $(.317)$ \\
\hline .282 & .589 \\
\hline$(.410)$ & $(.585)$ \\
\hline .034 & .030 \\
\hline$(.102)$ & $(.049)$ \\
\hline .387 & .416 \\
\hline$(.103)$ & $(.017)$ \\
\hline 2.024 & 1.167 \\
\hline$(1.500)$ & $(.623)$ \\
\hline 18.945 & 18.901 \\
\hline$(5.066)$ & (1.301) \\
\hline 9977147 & 9434329 \\
\hline (5703809) & $(5446965)$ \\
\hline 184.670 & 173.522 \\
\hline$(86.056)$ & $(25.717)$ \\
\hline 105.599 & 121.205 \\
\hline (76.381) & $(30.879)$ \\
\hline 131.112 & 147.440 \\
\hline$(39.260)$ & (16.261) \\
\hline 146.616 & 87.340 \\
\hline$(95.805)$ & (19.959) \\
\hline 93.978 & 118.020 \\
\hline$(24.861)$ & (8.971) \\
\hline 6.525 & 10.958 \\
\hline (3.309) & $(2.317)$ \\
\hline 1713.468 & 2097.032 \\
\hline (536.892) & (79.930) \\
\hline 4.222 & 17.959 \\
\hline (12.981) & $(22.648)$ \\
\hline 5.922 & 22.798 \\
\hline (17.047) & $(30.568)$ \\
\hline 1.223 & 5.080 \\
\hline$(3.667)$ & $(6.415)$ \\
\hline 20.215 & 86.754 \\
\hline$(66.512)$ & (119.309) \\
\hline 146.321 & 627.073 \\
\hline (476.925) & $(852.545)$ \\
\hline
\end{tabular}


Number of male katechisten

Number of female katechisten

Indigenous male teachers who are not

catechists

Indigenous female teachers who are not

catechists

Number of elementary schools

Number of Catholic boys in elementary

schools

Number of non-Catholic boys in elementary

schools

Number of Catholic girls in elementary schools

Number of non-Catholic girls in elementary

schools

Number of schools of higher degrees

Number of Catholic boys in schools of higher degrees

Number of non-Catholic boys in schools of

higher degrees

Number of Catholic girls in schools of higher

degrees

Number of non-Catholic girls in schools of higher degrees

\begin{tabular}{cc}
196.209 & 817.030 \\
$(604.075)$ & $(1068.675)$ \\
7.467 & 31.942 \\
$(24.221)$ & $(43.247)$ \\
328.869 & 1401.211 \\
$(966.579)$ & $(1641.535)$ \\
175.400 & 749.268 \\
$(558.229)$ & $(988.617)$ \\
240.043 & 1018.071 \\
$(670.013)$ & $(1103.703)$ \\
6011.584 & 25600.850 \\
$(18360.780)$ & $(31898.360)$ \\
2148.939 & 9115.085 \\
$(6403.939)$ & $(11002.95)$ \\
2860.690 & 12130.320 \\
$(9000.311)$ & $(15922.470)$ \\
572.831 & 2409.573 \\
$(1811.911)$ & $(3229.148)$ \\
34.138 & 144.908 \\
$(106.336)$ & $(187.083)$ \\
1786.387 & 7593.534 \\
$(5390.348)$ & $(9314.429)$ \\
1113.580 & 4744.297 \\
$(3382.543)$ & $(5857.138)$ \\
753.492 & 3174.937 \\
$(2159.483)$ & $(3642.790)$ \\
227.716 & 935.050 \\
$(641.119)$ & $(1090.069)$ \\
\hline$D H S .5 t a n$ \\
$(139)$
\end{tabular}

Notes: Weighted to national levels by weights provided by the DHS. Standard deviations in parentheses.

Table reports statistics at the unique level for states. States with Christian presence include Andhra Pradesh, Goa, Karnataka, Kerala, Maharashtra and Tamil Nadu. 
Table 2: OLS regression results for boys: Dependent variable - height-for-age

\begin{tabular}{|c|c|c|c|c|c|c|}
\hline & \multicolumn{3}{|c|}{ All States } & \multicolumn{3}{|c|}{ States with Christian Presence } \\
\hline & $0-11$ & $12-23$ & $24-35$ & $0-11$ & $12-23$ & $24-35$ \\
\hline \multirow[t]{2}{*}{ Christian } & $.596^{* *}$ & .047 & .088 & .362 & -.334 & -.073 \\
\hline & $(.223)$ & $(.242)$ & $(.306)$ & $(.298)$ & $(.268)$ & $(.305)$ \\
\hline \multirow[t]{2}{*}{ Upper-caste Hindu } & $.204^{* * *}$ & $.125^{* *}$ & .050 & .152 & .094 & .169 \\
\hline & $(.071)$ & $(.055)$ & $(.063)$ & $(.177)$ & $(.137)$ & $(.171)$ \\
\hline \multirow[t]{2}{*}{ Muslim } & .106 & $.142^{* *}$ & .015 & .236 & -.127 & .184 \\
\hline & $(.122)$ & $(.064)$ & $(.077)$ & $(.242)$ & $(.163)$ & $(.206)$ \\
\hline $\mathrm{N}$ & 4,807 & 5,114 & 4,875 & 895 & 967 & 907 \\
\hline $\mathrm{R}^{2}$ & .114 & .129 & .134 & .225 & .193 & .223 \\
\hline $\begin{array}{l}\text { Includes child, woman, household and state } \\
\text { specific characteristics }\end{array}$ & YES & YES & YES & YES & YES & YES \\
\hline Includes month and year of conception & YES & YES & YES & YES & YES & YES \\
\hline Dummies & & & & & & \\
\hline Includes time and state dummies and int. & YES & YES & YES & YES & YES & YES \\
\hline
\end{tabular}


Table 3: OLS regression results for girls: Dependent variable - height-for-age

\begin{tabular}{|c|c|c|c|c|c|c|}
\hline & \multicolumn{3}{|c|}{ All States } & \multicolumn{3}{|c|}{ States with Christian Presence } \\
\hline & $0-11$ & $12-23$ & $24-35$ & $0-11$ & $12-23$ & $24-35$ \\
\hline \multirow[t]{2}{*}{ Christian } & .162 & .124 & $.324^{*}$ & .251 & .306 & .206 \\
\hline & $(.190)$ & $(.127)$ & $(.180)$ & $(.302)$ & $(.219)$ & $(.258)$ \\
\hline \multirow[t]{2}{*}{ Upper-caste Hindu } & .088 & .018 & .001 & .171 & .284 & -.052 \\
\hline & $(.072)$ & $(.092)$ & $(.032)$ & $(.165)$ & $(.164)$ & $(.122)$ \\
\hline \multirow[t]{2}{*}{ Muslim } & .000 & -.001 & $-.190^{* *}$ & .107 & .143 & -.019 \\
\hline & $(.079)$ & $(.061)$ & $(.088)$ & $(.194)$ & $(.166)$ & $(.175)$ \\
\hline $\mathrm{N}$ & 4,638 & 5,010 & 4,630 & 828 & 990 & 909 \\
\hline $\mathrm{R}^{2}$ & .108 & .128 & .153 & .205 & .209 & .235 \\
\hline $\begin{array}{l}\text { Includes child, woman, household and state } \\
\text { specific characteristics }\end{array}$ & YES & YES & YES & YES & YES & YES \\
\hline $\begin{array}{l}\text { Includes month and year of conception } \\
\text { dummies }\end{array}$ & YES & YES & YES & YES & YES & YES \\
\hline Includes time and state dummies and int. & YES & YES & YES & YES & YES & YES \\
\hline
\end{tabular}


Table 4: First stage estimates: Dependent variable - Christian religious affiliation

\begin{tabular}{|c|c|c|c|}
\hline Variables & (1) & (2) & (3) \\
\hline Number of Protestant missions in district & $.006^{* * * 2}$ & $.007^{* * *}$ & $.007^{* *}$ \\
\hline as of 1910 & $(.002)$ & $(.002)$ & $(.003)$ \\
\hline Difference between year of birth and earliest & $.000^{* *}$ & $.000^{* * *}$ & $.000^{* *}$ \\
\hline year of establishment of Protestant mission & $(.000)$ & $(.000)$ & $(.000)$ \\
\hline Number of Protestant missions*difference & $-.000^{* * * 3}$ & $-.000^{* \text { *at }}$ & $-.000^{* * * * 4}$ \\
\hline b/w birth year and earliest year of Protestant est. & $(.000)$ & $(.000)$ & $(.000)$ \\
\hline Number of Catholic missions in district & .004 & .005 & .007 \\
\hline as of 1910 & (.007) & (.000) & $(.007)$ \\
\hline Difference between year of birth and earliest & -.000 & -.000 & $-.000^{*}$ \\
\hline year of establishment of Catholic mission & $(.000)$ & $(.000)$ & $(.000)$ \\
\hline Number of Catholic missions*difference & .000 & .000 & .000 \\
\hline $\mathrm{b} / \mathrm{w}$ birth year and earliest year of Catholic est. & $(.000)$ & (.000) & $(.000)$ \\
\hline $\begin{array}{l}\text { Total number of wars mission establishing countries } \\
\text { were engaged in as of } 1910\end{array}$ & & $\begin{array}{l}-.001 \\
(.001)\end{array}$ & $\begin{array}{l}-.001^{* * * *} \\
(.000)\end{array}$ \\
\hline $\begin{array}{l}\text { Number of times there were intense famines as of } \\
1910\end{array}$ & & & $.019^{* *}$ \\
\hline Total length of time famine lasted in years & & & $\begin{array}{l}-.006^{* * * *} \\
(.002)\end{array}$ \\
\hline Total number of cyclones as of 1910 & & & .002 \\
\hline Total number of earthquakes as of 1910 & & & -.071 \\
\hline & & & $(.070)$ \\
\hline $\begin{array}{l}\text { Ratio of deaths from injuries (suicides, wounding, } \\
\text { accidents, snake-bites) per } 1000 \text { people }\end{array}$ & & & $\begin{array}{l}-.032 \\
(.044)\end{array}$ \\
\hline$F$-statistic & $\begin{array}{l}6.050 \\
{[.001]}\end{array}$ & $\begin{array}{l}6.100 \\
{[.000]}\end{array}$ & $\begin{array}{c}39.780 \\
{[.000]}\end{array}$ \\
\hline $\mathrm{N}$ & 44,116 & 44,116 & 30,944 \\
\hline $\mathrm{R}^{2}$ & 0.266 & 0.266 & 0.306 \\
\hline Includes time and state dummies and inte & YES & YES & YES \\
\hline
\end{tabular}

Notes: Standard errors in parentheses are clustered by state. The notation $* * *$ is $\mathrm{p}<0.01, * *$ is $\mathrm{p}<0.05$, $*$ is $\mathrm{p}<0.10$. The $F$-statistic tests the null that the instruments are jointly equal to zero. $p$-values reported in square brackets. 
Table 5: IV regression results for boys: Dependent variable - height-for-age

\begin{tabular}{|c|c|c|c|c|c|c|}
\hline & \multicolumn{3}{|c|}{ All States } & \multicolumn{3}{|c|}{ States with Christian Presence } \\
\hline & $0-11$ & $12-23$ & $24-35$ & $0-11$ & $12-23$ & $24-35$ \\
\hline \multirow[t]{2}{*}{ Christian } & 3.416 & .533 & 3.461 & 5.529 & -2.205 & 609 \\
\hline & $(2.988)$ & $(2.209)$ & $(2.618)$ & $(3.987)$ & $(3.642)$ & $(2.567)$ \\
\hline \multirow[t]{2}{*}{ Upper-caste Hindu } & $.526^{*}$ & .148 & .146 & 1.504 & -.035 & .098 \\
\hline & $(.294)$ & $(.145)$ & $(.151)$ & $(.926)$ & $(.445)$ & $(.356)$ \\
\hline \multirow[t]{2}{*}{ Muslim } & .390 & .146 & .171 & 1.624 & -.277 & .215 \\
\hline & $(.319)$ & $(.149)$ & $(.194)$ & $(1.030)$ & $(.449)$ & $(.456)$ \\
\hline \multirow[t]{2}{*}{ Hansen's $J$-statistic } & 11.735 & 11.343 & 8.598 & 9.934 & 15.092 & 13.785 \\
\hline & {$[.384]$} & {$[.415]$} & {$[.659]$} & {$[.446]$} & {$[.129]$} & {$[.183]$} \\
\hline $\mathrm{N}$ & 3,327 & 3,516 & 3,262 & 609 & 686 & 608 \\
\hline $\mathrm{R}^{2}$ & .092 & .138 & .083 & & .194 & .201 \\
\hline $\begin{array}{l}\text { Includes child, woman, household and state } \\
\text { specific characteristics }\end{array}$ & YES & YES & YES & YES & YES & YES \\
\hline $\begin{array}{l}\text { Includes month and year of conception } \\
\text { dummies }\end{array}$ & YES & YES & YES & YES & YES & YES \\
\hline Includes time and state dummies and int. & YES & YES & YES & YES & YES & YES \\
\hline
\end{tabular}


Table 6: IV regression results for girls: Dependent variable - height-for-age

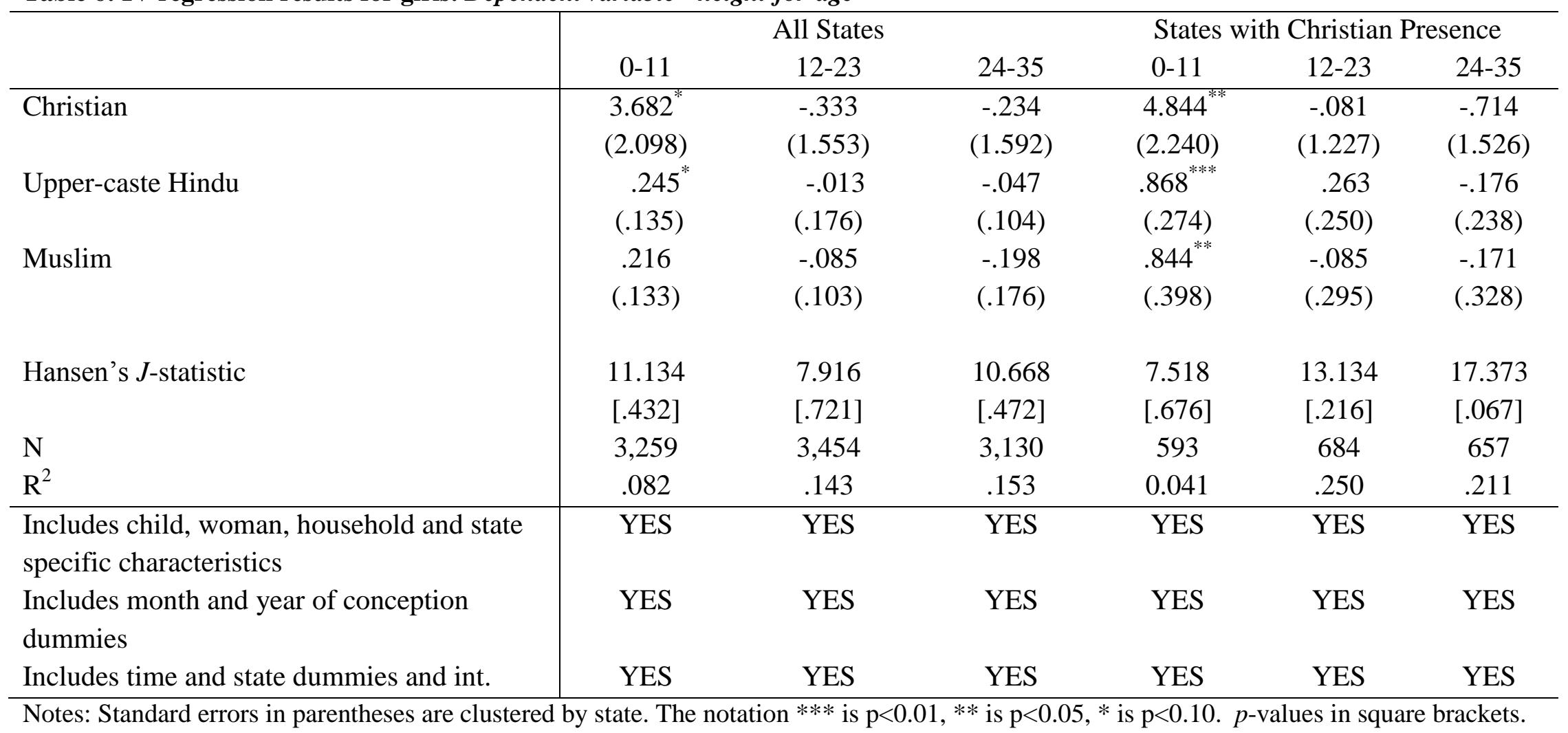


Table 7: IV regression results for boys: Dependent variable - height-for-age

\begin{tabular}{|c|c|c|c|c|c|c|}
\hline & \multicolumn{3}{|c|}{ All States } & \multicolumn{3}{|c|}{ States with Christian Presence } \\
\hline & $0-11$ & $12-23$ & $24-35$ & $0-11$ & $12-23$ & $24-35$ \\
\hline \multirow[t]{2}{*}{ Christian } & 3.126 & .365 & 3.573 & 4.553 & -3.614 & -.582 \\
\hline & $(2.757)$ & $(2.170)$ & $(2.707)$ & $(3.027)$ & $(2.939)$ & $(2.320)$ \\
\hline \multirow[t]{2}{*}{ Upper-caste Hindu } & $.505^{*}$ & .140 & .151 & $1.280^{*}$ & -.192 & -.045 \\
\hline & $(.278)$ & $(.143)$ & $(.149)$ & $(.718)$ & $(.369)$ & $(.348)$ \\
\hline \multirow[t]{2}{*}{ Muslim } & .358 & .136 & .175 & $1.369^{*}$ & -.420 & .041 \\
\hline & $(.311)$ & $(.144)$ & $(.194)$ & $(.789)$ & $(.393)$ & $(.401)$ \\
\hline \multirow{2}{*}{$\begin{array}{l}\text { Number of cities at or above } 1500 \text { feet in } \\
\text { district as of } 1893\end{array}$} & .004 & .001 & -.002 & $.018^{* *}$ & -.006 & -.007 \\
\hline & $(.005)$ & $(.003)$ & $(.005)$ & $(.008)$ & $(.009)$ & $(.008)$ \\
\hline \multirow{2}{*}{$\begin{array}{l}\text { Number of cities on railway lines in district } \\
\text { as of } 1893\end{array}$} & .023 & .009 & .003 & .013 & .013 & .006 \\
\hline & $(.014)$ & $(.010)$ & $(.020)$ & $(.029)$ & $(.021)$ & $(.015)$ \\
\hline \multirow{2}{*}{$\begin{array}{l}\text { Number of cities on navigable canals in } \\
\text { district as of } 1893\end{array}$} & -.001 & -.001 & .011 & .026 & $-.042^{* *}$ & -.005 \\
\hline & $(.022)$ & $(.012)$ & $(.014)$ & $(.055)$ & $(.020)$ & $(.012)$ \\
\hline \multirow[t]{2}{*}{ Hansen's $J$-statistic } & 14.880 & 10.316 & 10.129 & 8.793 & 14.954 & 14.541 \\
\hline & {$[.248]$} & {$[.502]$} & {$[.519]$} & {$[.552]$} & [.134] & {$[.150]$} \\
\hline $\mathrm{N}$ & 3,327 & 3,516 & 3,262 & 609 & 686 & 608 \\
\hline $\mathrm{R}^{2}$ & .101 & .139 & .079 & 0.059 & .145 & .207 \\
\hline
\end{tabular}

Notes: Standard errors in parentheses are clustered by state. The notation $* * *$ is $\mathrm{p}<0.01, * *$ is $\mathrm{p}<0.05, *$ is $\mathrm{p}<0.10 . p$-values in square brackets.

Regressions include controls for child, woman, household and state -specific characteristics, month and year of conception dummies, and time and state dummies and their interactions. 
Table 8: IV regression results for girls: Dependent variable - height-for-age

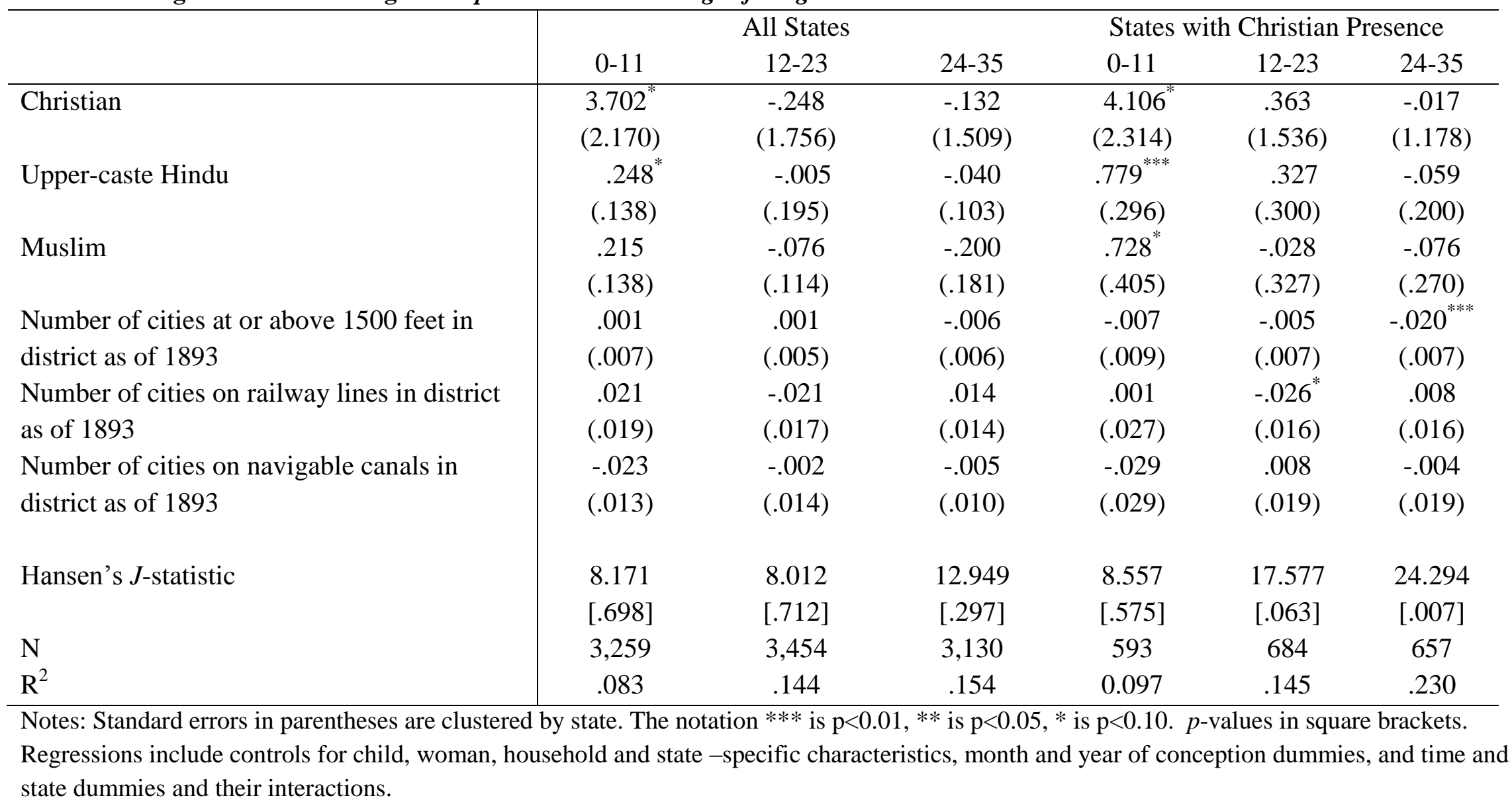




\begin{tabular}{|c|c|c|c|c|c|c|}
\hline & \multicolumn{3}{|c|}{ All States } & \multicolumn{3}{|c|}{ States with Christian Presence } \\
\hline & $0-11$ & $0-11$ & $0-11$ & $0-11$ & $0-11$ & $0-11$ \\
\hline \multirow[t]{2}{*}{ Christian } & 3.123 & 3.126 & 4.165 & 4.290 & 4.608 & 4.501 \\
\hline & $(2.705)$ & $(2.757)$ & $(3.692)$ & $(3.280)$ & $(3.048)$ & $(3.054)$ \\
\hline \multirow[t]{2}{*}{ Upper-caste Hindu } & $.506^{*}$ & $.505^{*}$ & $.561^{*}$ & 1.226 & $1.293^{*}$ & $1.266^{*}$ \\
\hline & $(.274)$ & $(.278)$ & $(.319)$ & $(.781)$ & $(.723)$ & $(.724)$ \\
\hline \multirow[t]{2}{*}{ Muslim } & .363 & .358 & .425 & 1.286 & $1.384^{*}$ & $1.343^{*}$ \\
\hline & $(.304)$ & $(.311)$ & $(.330)$ & $(.837)$ & $(.794)$ & $(.792)$ \\
\hline \multirow[t]{2}{*}{ Per capita calories } & .002 & & & -.013 & & \\
\hline & $(.003)$ & & & $(.017)$ & & \\
\hline \multirow[t]{2}{*}{ Per capita protein } & -.001 & & & .346 & & \\
\hline & $(.064)$ & & & $(.410)$ & & \\
\hline \multirow[t]{2}{*}{ Per capita fat } & -.022 & & & .124 & & \\
\hline & $(.017)$ & & & $(.116)$ & & \\
\hline \multirow[t]{2}{*}{ Consumer price index - AL } & & $-.008^{* * *}$ & & & -3.967 & \\
\hline & & $(.003)$ & & & $(2.757)$ & \\
\hline \multirow[t]{2}{*}{ Malaria/TB } & & & 100.079 & & & -975.754 \\
\hline & & & (158.201) & & & (1102.449) \\
\hline \multirow[t]{2}{*}{ Hansen's $J$-statistic } & 11.333 & 11.412 & 12.224 & 9.331 & 8.793 & 8.960 \\
\hline & [.416] & [.409] & [.347] & [.501] & [.552] & [.536] \\
\hline $\mathrm{N}$ & 3,327 & 3,327 & 2,866 & 609 & 609 & 609 \\
\hline $\mathrm{R}^{2}$ & .102 & .101 & 0.074 & .088 & .053 & .065 \\
\hline
\end{tabular}

Notes: Standard errors in parentheses are clustered by state. The notation $* * *$ is $\mathrm{p}<0.01$, ** is $\mathrm{p}<0.05, *$ is $\mathrm{p}<0.10 . p$-values in square brackets.

Regressions include controls for child, woman, household and state -specific characteristics, month and year of conception dummies, and time and state dummies and their interactions. Regressions include controls for endogeneity in location of missions, that is, cities in the district at or above 1500 feet, cities in the district on railway lines, and cities in the district on navigable canals as of 1893. 


\begin{tabular}{|c|c|c|c|c|c|c|}
\hline & \multicolumn{3}{|c|}{ All States } & \multicolumn{3}{|c|}{ States with Christian Presence } \\
\hline & $0-11$ & $0-11$ & $0-11$ & $0-11$ & $0-11$ & $0-11$ \\
\hline \multirow[t]{2}{*}{ Christian } & $3.794^{*}$ & $3.702^{*}$ & $7.975^{* *}$ & $4.354^{*}$ & $4.107^{*}$ & $4.166^{*}$ \\
\hline & $(2.187)$ & $(2.170)$ & $(3.740)$ & $(2.314)$ & $(2.314)$ & $(2.338)$ \\
\hline \multirow[t]{2}{*}{ Upper-caste Hindu } & $.255^{*}$ & $.248^{*}$ & $.400^{* *}$ & $.805^{* * *}$ & $.779^{* * *}$ & $.793^{* * *}$ \\
\hline & $(.140)$ & $(.138)$ & $(.157)$ & $(.300)$ & $(.296)$ & $(.295)$ \\
\hline \multirow[t]{2}{*}{ Muslim } & .222 & .215 & $.379^{* *}$ & $.739^{*}$ & $.727^{*}$ & $.740^{*}$ \\
\hline & $(.138)$ & $(.138)$ & $(.184)$ & $(.411)$ & $(.405)$ & $(.406)$ \\
\hline \multirow[t]{2}{*}{ Per capita calories } & -.002 & & & $-.026^{* * *}$ & & \\
\hline & $(.002)$ & & & $(.009)$ & & \\
\hline \multirow[t]{2}{*}{ Per capita protein } & .042 & & & $.594^{* * *}$ & & \\
\hline & $(.061)$ & & & $(.225)$ & & \\
\hline \multirow[t]{2}{*}{ Per capita fat } & .026 & & & $.263^{* * *}$ & & \\
\hline & $(.028)$ & & & $(.083)$ & & \\
\hline \multirow[t]{2}{*}{ Consumer Price Index - AL } & & $.003^{* *}$ & & & .544 & \\
\hline & & $(.001)$ & & & $(1.912)$ & \\
\hline \multirow[t]{2}{*}{ Malaria/TB } & & & -136.192 & & & -1417.047 \\
\hline & & & (324.993) & & & (1474.003) \\
\hline \multirow[t]{2}{*}{ Hansen's $J$-statistic } & 7.952 & 8.171 & 9.377 & 8.721 & 8.557 & 9.490 \\
\hline & {$[.718]$} & {$[.698]$} & {$[.587]$} & {$[.559]$} & {$[.575]$} & {$[.486]$} \\
\hline $\mathrm{N}$ & 3,259 & 3,259 & 2,807 & 593 & 593 & 593 \\
\hline $\mathrm{R}^{2}$ & .081 & .083 & & .094 & .097 & .095 \\
\hline
\end{tabular}

Notes: Standard errors in parentheses are clustered by state. The notation $* * *$ is $\mathrm{p}<0.01, * *$ is $\mathrm{p}<0.05, *$ is $\mathrm{p}<0.10 . p$-values in square brackets.

Regressions include controls for child, woman, household and state -specific characteristics, month and year of conception dummies, and time and state dummies and their interactions. Regressions include controls for endogeneity in location of missions, that is, cities in the district at or above 1500 feet, cities in the district on railway lines, and cities in the district on navigable canals as of 1893. 
Table 11: IV regression results for boys: Dependent variable - height-for-age

\begin{tabular}{|c|c|c|c|c|c|c|c|c|}
\hline & \multicolumn{4}{|c|}{ All States } & \multicolumn{4}{|c|}{ States with Christian Presence } \\
\hline & $0-11$ & $0-11$ & $0-11$ & $0-11$ & $0-11$ & $0-11$ & $0-11$ & $0-11$ \\
\hline \multirow[t]{2}{*}{ Christian } & 3.123 & 3.150 & 3.116 & 3.067 & 4.302 & 4.549 & 4.569 & 4.730 \\
\hline & $(2.730)$ & $(2.763)$ & $(2.748)$ & $(2.737)$ & $(2.989)$ & $(3.024)$ & $(3.049)$ & $(3.051)$ \\
\hline \multirow[t]{2}{*}{ Upper-caste Hindu } & $.503^{*}$ & $.507^{*}$ & $.504^{*}$ & $.501^{*}$ & $1.213^{*}$ & $1.279^{*}$ & $1.279^{*}$ & $1.320^{*}$ \\
\hline & $(.276)$ & $(.279)$ & $(.278)$ & $(.276)$ & $(.704)$ & $(.718)$ & $(.724)$ & $(.733)$ \\
\hline \multirow[t]{2}{*}{ Muslim } & .363 & .360 & .357 & .354 & $1.287^{*}$ & $1.368^{*}$ & $1.367^{*}$ & $1.413^{*}$ \\
\hline & $(.309)$ & $(.313)$ & $(.311)$ & $(.308)$ & $(.773)$ & $(.789)$ & $(.796)$ & $(.807)$ \\
\hline \multirow[t]{2}{*}{ Infant mortality rate } & -.023 & & & & $.138^{* *}$ & & & \\
\hline & $(.018)$ & & & & $(.057)$ & & & \\
\hline \multirow[t]{2}{*}{ Gini coefficient } & & 2.460 & & & & -.515 & & \\
\hline & & $(2.546)$ & & & & (16.189) & & \\
\hline \multirow[t]{2}{*}{ Air temperature } & & & .024 & & & & -.609 & \\
\hline & & & $(.168)$ & & & & $(.676)$ & \\
\hline \multirow[t]{2}{*}{ Public Subsidies } & & & & -.000 & & & & .000 \\
\hline & & & & $(.000)$ & & & & $(.000)$ \\
\hline \multirow[t]{2}{*}{ Hansen's $J$-statistic } & 11.239 & 11.376 & 11.447 & 11.446 & 9.236 & 8.790 & 8.905 & 8.749 \\
\hline & {$[.423]$} & [.412] & {$[.407]$} & {$[.407]$} & {$[.510]$} & {$[.552]$} & {$[.541]$} & {$[.556]$} \\
\hline $\mathrm{N}$ & 3,327 & 3,327 & 3,327 & 3,327 & 609 & 609 & 609 & 609 \\
\hline $\mathrm{R}^{2}$ & .101 & .100 & 0.101 & .102 & .086 & .059 & .058 & .041 \\
\hline
\end{tabular}

Notes: Standard errors in parentheses are clustered by state. The notation $* * *$ is $\mathrm{p}<0.01, * *$ is $\mathrm{p}<0.05, *$ is $\mathrm{p}<0.10 . p$-values in square brackets.

Regressions include controls for child, woman, household and state -specific characteristics, month and year of conception dummies, and time and state dummies and their interactions. Regressions include controls for endogeneity in location of missions, that is, cities in the district at or above 1500 feet, cities in the district on railway lines, and cities in the district on navigable canals as of 1893. 
Table 12: IV regression results for girls: Dependent variable - height-for-age

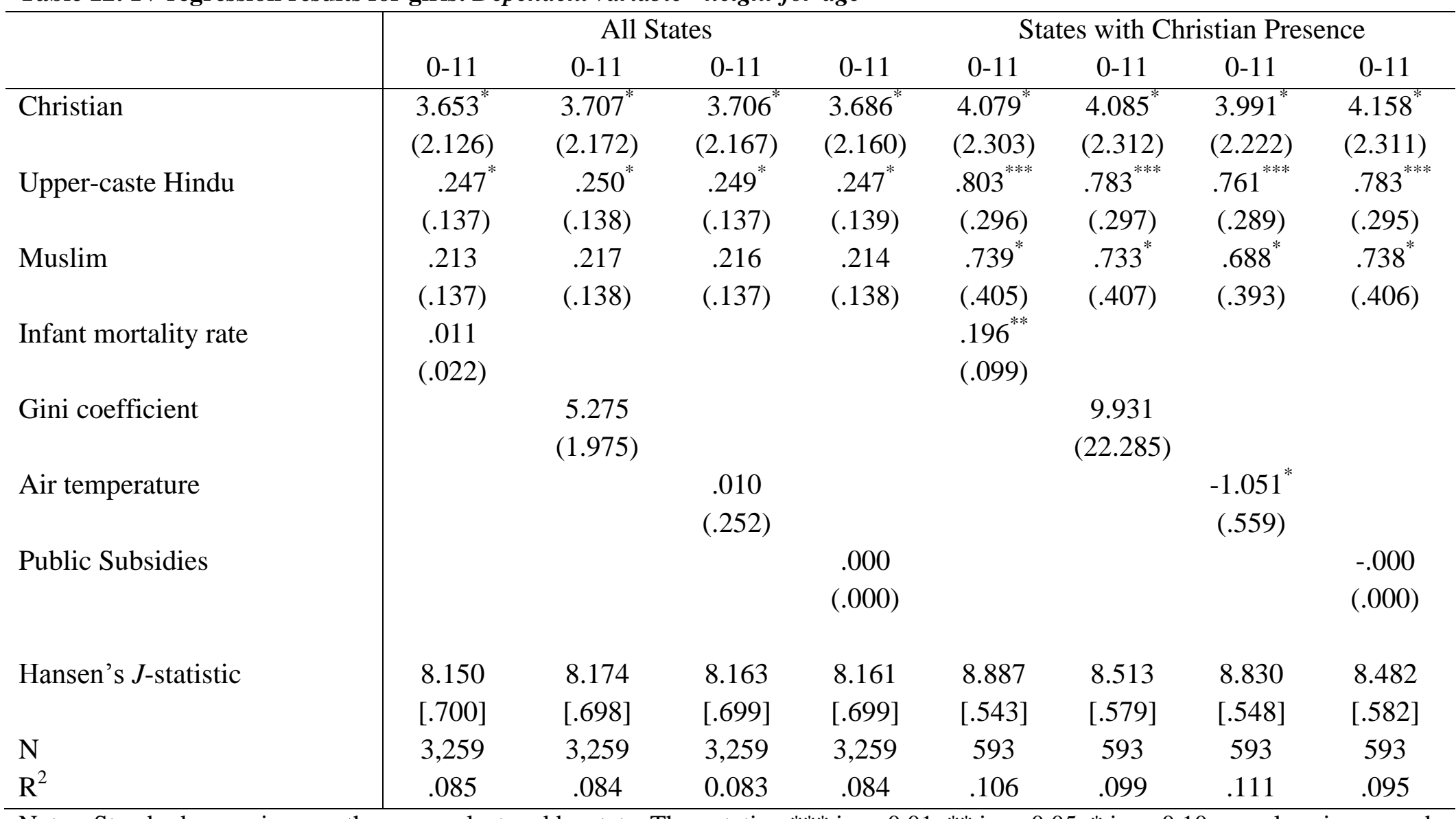

Notes: Standard errors in parentheses are clustered by state. The notation $* * *$ is $\mathrm{p}<0.01, * *$ is $\mathrm{p}<0.05, *$ is $\mathrm{p}<0.10 . p$-values in square brackets.

Regressions include controls for child, woman, household and state -specific characteristics, month and year of conception dummies, and time and state dummies and their interactions. Regressions include controls for endogeneity in location of missions, that is, cities in the district at or above 1500 feet, cities in the district on railway lines, and cities in the district on navigable canals as of 1893. 
Table 13: IV regression results for boys: Dependent variable - height-for-age

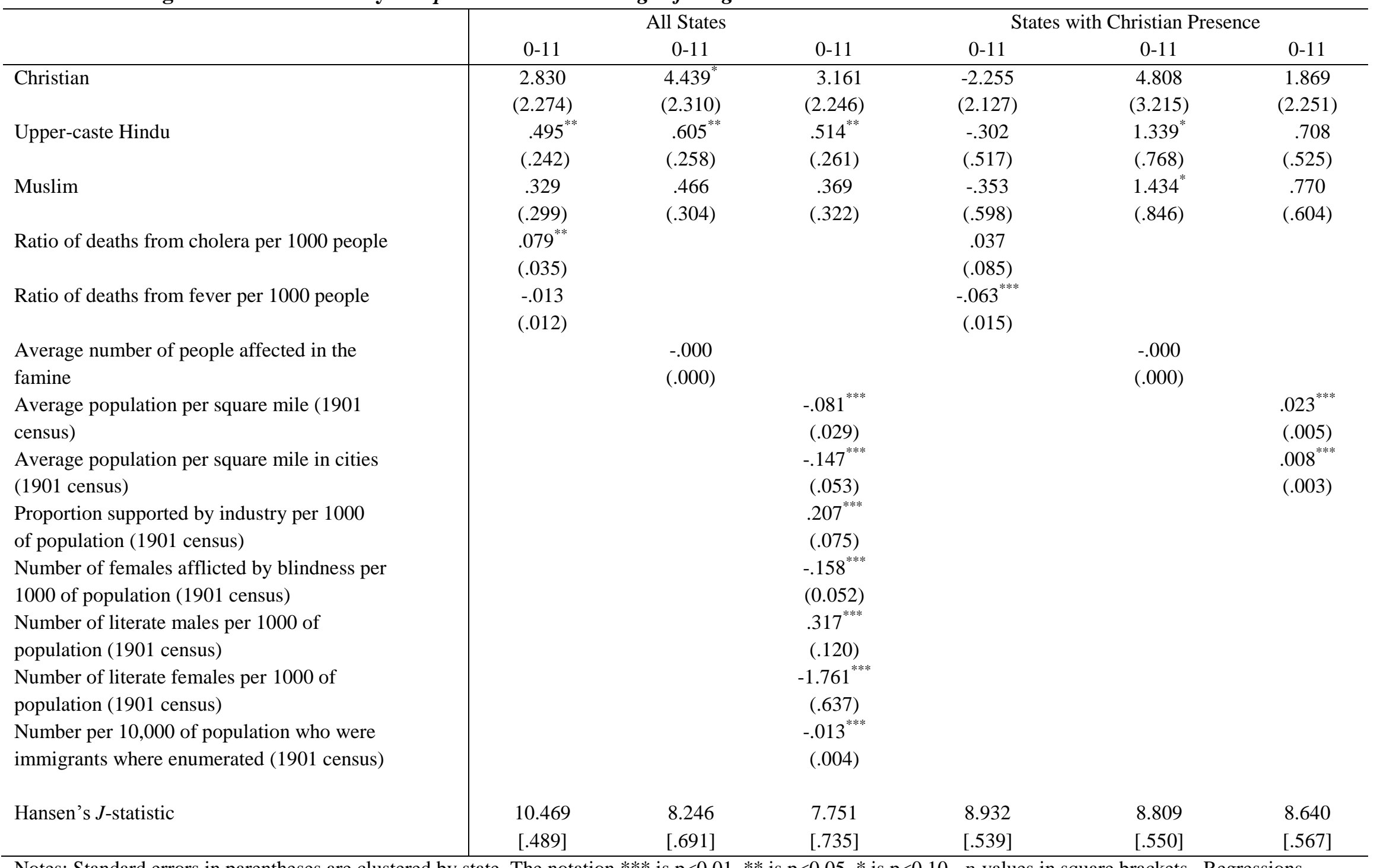

Notes: Standard errors in parentheses are clustered by state. The notation $* * *$ is $\mathrm{p}<0.01, * *$ is $\mathrm{p}<0.05, *$ is $\mathrm{p}<0.10 . p$-values in square brackets. Regressions include all controls as before. Number of observations and $\mathrm{R}^{2}$ in the range of those reported above. Some 1901 census variables not identified (dropped from regression) in states with Christian presence. 
Table 14: IV regression results for girls: Dependent variable - height-for-age

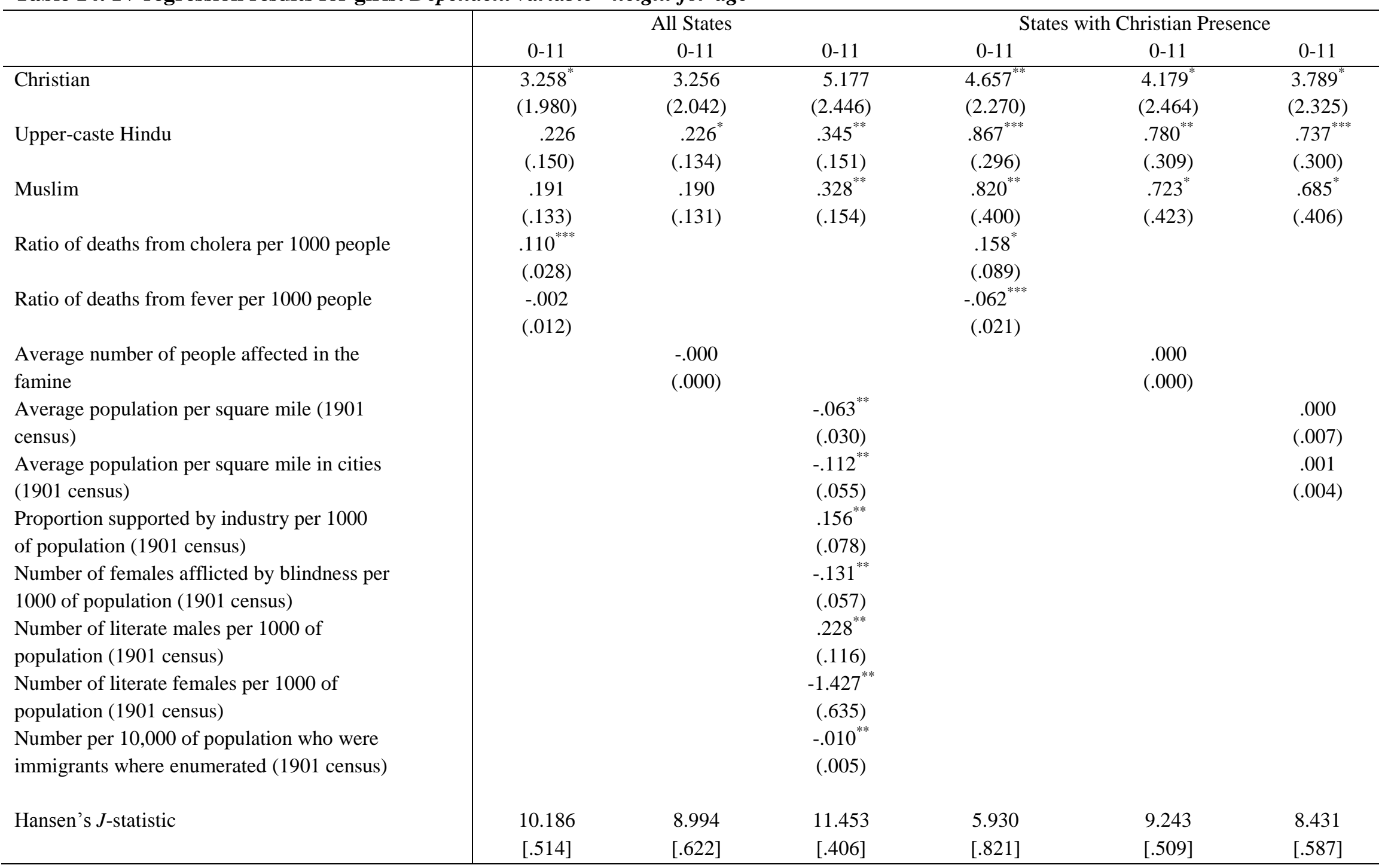

Notes: Standard errors in parentheses are clustered by state. The notation $* * *$ is $\mathrm{p}<0.01, * *$ is $\mathrm{p}<0.05, *$ is $\mathrm{p}<0.10$. $p$-values in square brackets. Regressions include all controls as before. Number of observations and $\mathrm{R}^{2}$ in the range of those reported above. Some 1901 census variables not identified (dropped from regression) in states with Christian presence. 
Table 15: IV regression results for boys: Dependent variable - height-for-age

\begin{tabular}{|c|c|c|c|c|}
\hline & \multicolumn{2}{|c|}{ All States } & \multicolumn{2}{|c|}{ States with Christian Presence } \\
\hline & $0-11$ & $0-11$ & $0-11$ & $0-11$ \\
\hline \multirow[t]{2}{*}{ Christian } & 2.873 & $3.706^{*}$ & 2.116 & 5.529 \\
\hline & $(2.248)$ & $(2.129)$ & $(2.010)$ & $(3.427)$ \\
\hline \multirow[t]{2}{*}{ Upper-caste Hindu } & $.485^{* *}$ & $.545^{* *}$ & .685 & $1.515^{*}$ \\
\hline & $(.233)$ & $(.242)$ & $(.482)$ & $(.854)$ \\
\hline \multirow[t]{2}{*}{ Muslim } & .341 & .402 & .733 & $1.655^{*}$ \\
\hline & $(.268)$ & $(.285)$ & $(.532)$ & $(.958)$ \\
\hline \multirow[t]{2}{*}{ Number of hospitals } & -.029 & & -.055 & \\
\hline & $(.032)$ & & $(.044)$ & \\
\hline \multirow[t]{2}{*}{ Number of pharmacies } & .006 & & $.035^{*}$ & \\
\hline & $(.012)$ & & $(.018)$ & \\
\hline \multirow{2}{*}{ Number of print shops } & .076 & & .039 & \\
\hline & $(.099)$ & & $(.124)$ & \\
\hline \multirow[t]{2}{*}{ Number of native/indigenous Laien brothers } & & $-.018^{*}$ & & -.000 \\
\hline & & $(.011)$ & & $(.018)$ \\
\hline \multirow{2}{*}{$\begin{array}{l}\text { Number of native/indigenous Schwestern } \\
\text { sisters }\end{array}$} & & $.004^{* *}$ & & .000 \\
\hline & & $(.002)$ & & $(.004)$ \\
\hline \multirow[t]{2}{*}{ Number of male katechisten } & & -.000 & & .001 \\
\hline & & $(.000)$ & & $(.004)$ \\
\hline \multirow[t]{2}{*}{ Number of female katechisten } & & -.006 & & -.034 \\
\hline & & $(.010)$ & & $(.035)$ \\
\hline \multirow{2}{*}{$\begin{array}{l}\text { Indigenous male teachers who are not } \\
\text { catechists }\end{array}$} & & .001 & & -.000 \\
\hline & & $(.001)$ & & $(.001)$ \\
\hline \multirow{2}{*}{$\begin{array}{l}\text { Indigenous female teachers who are not } \\
\text { catechists }\end{array}$} & & -.002 & & .000 \\
\hline & & $(.002)$ & & $(.004)$ \\
\hline \multirow[t]{2}{*}{ Hansen's $J$-statistic } & 12.433 & 9.709 & 12.317 & 8.826 \\
\hline & [.332] & {$[.557]$} & {$[.264]$} & [.549] \\
\hline
\end{tabular}

Notes: Standard errors in parentheses are clustered by state. The notation *** is $\mathrm{p}<0.01, * *$ is $\mathrm{p}<0.05, *$ is $\mathrm{p}<0.10 . \quad p$-values in square brackets. Regressions include all controls as before. Number of observations and $\mathrm{R}^{2}$ in the range of those reported above. 
Table 16: IV regression results for girls: Dependent variable - height-for-age

\begin{tabular}{|c|c|c|c|c|}
\hline & \multicolumn{2}{|c|}{ All States } & \multicolumn{2}{|c|}{ States with Christian Presence } \\
\hline & $0-11$ & $0-11$ & $0-11$ & $0-11$ \\
\hline \multirow[t]{2}{*}{ Christian } & 3.325 & 3.549 & 2.437 & 3.090 \\
\hline & $(2.296)$ & $(2.174)$ & $(2.383)$ & $(2.413)$ \\
\hline \multirow[t]{2}{*}{ Upper-caste Hindu } & $.229^{*}$ & $.239^{*}$ & $.559^{*}$ & $.663^{* *}$ \\
\hline & $(.139)$ & $(.127)$ & $(.312)$ & $(.330)$ \\
\hline \multirow[t]{2}{*}{ Muslim } & .197 & $.205^{*}$ & .476 & .567 \\
\hline & $(.143)$ & $(.117)$ & $(.383)$ & $(.404)$ \\
\hline \multirow[t]{2}{*}{ Number of hospitals } & -.014 & & .010 & \\
\hline & $(.025)$ & & $(.060)$ & \\
\hline \multirow{2}{*}{ Number of pharmacies } & .001 & & -.011 & \\
\hline & $(.008)$ & & $(.027)$ & \\
\hline \multirow{2}{*}{ Number of print shops } & .047 & & .026 & \\
\hline & $(.073)$ & & $(.156)$ & \\
\hline \multirow[t]{2}{*}{ Number of native/indigenous Laien brothers } & & .015 & & .025 \\
\hline & & $(.011)$ & & $(.017)$ \\
\hline \multirow{2}{*}{$\begin{array}{l}\text { Number of native/indigenous Schwestern } \\
\text { sisters }\end{array}$} & & -.001 & & -.004 \\
\hline & & $(.002)$ & & $(.004)$ \\
\hline \multirow[t]{2}{*}{ Number of male katechisten } & & -.000 & & -.001 \\
\hline & & $(.000)$ & & $(.004)$ \\
\hline \multirow[t]{2}{*}{ Number of female katechisten } & & $-.053^{* * *}$ & & $-.089^{* * * *}$ \\
\hline & & $(.019)$ & & $(.027)$ \\
\hline \multirow{2}{*}{$\begin{array}{l}\text { Indigenous male teachers who are not } \\
\text { catechists }\end{array}$} & & -.000 & & .000 \\
\hline & & $(.001)$ & & $(.001)$ \\
\hline \multirow{2}{*}{$\begin{array}{l}\text { Indigenous female teachers who are not } \\
\text { catechists }\end{array}$} & & .002 & & .004 \\
\hline & & $(.003)$ & & $(.003)$ \\
\hline \multirow[t]{2}{*}{ Hansen's $J$-statistic } & 9.694 & 9.135 & 9.522 & 7.785 \\
\hline & {$[.558]$} & [.609] & [.483] & {$[.650]$} \\
\hline
\end{tabular}

Notes: Standard errors in parentheses are clustered by state. The notation *** is $\mathrm{p}<0.01, * *$ is $\mathrm{p}<0.05, *$ is $\mathrm{p}<0.10 . \quad p$-values in square brackets. Regressions include all controls as before. Number of observations and $\mathrm{R}^{2}$ in the range of those reported above. 
Table 17: IV regression results for boys: Dependent variable - height-for-age

\begin{tabular}{|c|c|c|c|c|}
\hline & \multicolumn{2}{|c|}{ All States } & \multicolumn{2}{|c|}{ States with Christian Presence } \\
\hline & $0-11$ & $0-11$ & $0-11$ & $0-11$ \\
\hline Christian & $\begin{array}{c}2.292 \\
(1.530)\end{array}$ & $\begin{array}{c}1.935 \\
(1.490)\end{array}$ & $\begin{array}{c}1.315 \\
(1.802)\end{array}$ & $\begin{array}{c}.704 \\
(1.613)\end{array}$ \\
\hline Upper-caste Hindu & $\begin{array}{l}.435^{* * *} \\
(.152)\end{array}$ & $\begin{array}{l}.420^{* * * *} \\
(.150)\end{array}$ & $\begin{array}{l}.487 \\
(.445)\end{array}$ & $\begin{array}{l}.353 \\
(.410)\end{array}$ \\
\hline Muslim & $\begin{array}{l}.288^{*} \\
(.172)\end{array}$ & $\begin{array}{l}.261 \\
(.193)\end{array}$ & $\begin{array}{c}.495 \\
(.494)\end{array}$ & $\begin{array}{l}.348 \\
(.464)\end{array}$ \\
\hline Number of elementary schools & $\begin{array}{l}.001 \\
(.001)\end{array}$ & & $\begin{array}{c}.002 \\
(.002)\end{array}$ & \\
\hline $\begin{array}{l}\text { Number of Catholic boys in elementary } \\
\text { schools }\end{array}$ & $\begin{array}{l}-.000 \\
(.000)\end{array}$ & & $\begin{array}{l}-.000 \\
(.000)\end{array}$ & \\
\hline $\begin{array}{l}\text { Number of non-Catholic boys in elementary } \\
\text { schools }\end{array}$ & $\begin{array}{l}-.000 \\
(.000)\end{array}$ & & $\begin{array}{l}-.000 \\
(.000)\end{array}$ & \\
\hline Number of Catholic girls in elementary schools & $\begin{array}{l}-.000 \\
(.001)\end{array}$ & & $\begin{array}{l}-.000 \\
(.000)\end{array}$ & \\
\hline $\begin{array}{l}\text { Number of non-Catholic girls in elementary } \\
\text { schools }\end{array}$ & $\begin{array}{l}.000 \\
(.001)\end{array}$ & & $\begin{array}{c}.001 \\
(.001)\end{array}$ & \\
\hline Number of schools of higher degrees & & $\begin{array}{l}.018^{* *} \\
(.008)\end{array}$ & & $\begin{array}{l}.010 \\
(.023)\end{array}$ \\
\hline $\begin{array}{l}\text { Number of Catholic boys in schools of higher } \\
\text { degrees }\end{array}$ & & $\begin{array}{l}-.000 \\
(.000)\end{array}$ & & $\begin{array}{l}-.000 \\
(.001)\end{array}$ \\
\hline $\begin{array}{l}\text { Number of non-Catholic boys in schools of } \\
\text { higher degrees }\end{array}$ & & $\begin{array}{l}-.001^{* *} \\
(.000)\end{array}$ & & $\begin{array}{l}-.000 \\
(.002)\end{array}$ \\
\hline $\begin{array}{l}\text { Number of Catholic girls in schools of higher } \\
\text { degrees }\end{array}$ & & $\begin{array}{c}.001 \\
(.000)\end{array}$ & & $\begin{array}{l}.000 \\
(.001)\end{array}$ \\
\hline $\begin{array}{l}\text { Number of non-Catholic girls in schools of } \\
\text { higher degrees }\end{array}$ & & $\begin{array}{l}-.000 \\
(.001)\end{array}$ & & $\begin{array}{l}.001 \\
(.001)\end{array}$ \\
\hline Hansen's $J$-statistic & $\begin{array}{l}10.354 \\
{[.499]}\end{array}$ & $\begin{array}{l}10.988 \\
{[.444]}\end{array}$ & $\begin{array}{l}13.901 \\
{[.178]}\end{array}$ & $\begin{array}{l}12.539 \\
{[.251]}\end{array}$ \\
\hline
\end{tabular}

Notes: Standard errors in parentheses are clustered by state. The notation $* * *$ is $\mathrm{p}<0.01, * *$ is $\mathrm{p}<0.05, *$ is $\mathrm{p}<0.10 . \quad p$-values in square brackets. Regressions include all controls as before. Number of observations and $\mathrm{R}^{2}$ in the range of those reported above. 
Table 18: IV regression results for girls: Dependent variable - height-for-age

\begin{tabular}{|c|c|c|c|c|}
\hline & \multicolumn{2}{|c|}{ All States } & \multicolumn{2}{|c|}{ States with Christian Presence } \\
\hline & $0-11$ & $0-11$ & $0-11$ & $0-11$ \\
\hline Christian & $\begin{array}{c}3.004 \\
(2.398)\end{array}$ & $\begin{array}{c}3.626 \\
(2.417)\end{array}$ & $\begin{array}{c}2.315 \\
(2.684)\end{array}$ & $\begin{array}{c}2.360 \\
(2.613)\end{array}$ \\
\hline Upper-caste Hindu & $\begin{array}{r}.211 \\
(.129)\end{array}$ & $\begin{array}{c}.251^{*} \\
(.135)\end{array}$ & $\begin{array}{c}.547 \\
(.353)\end{array}$ & $\begin{array}{c}.542 \\
(.336)\end{array}$ \\
\hline Muslim & $\begin{array}{l}.176 \\
(.124)\end{array}$ & $\begin{array}{c}.222 \\
(.140)\end{array}$ & $\begin{array}{l}.450 \\
(.418)\end{array}$ & $\begin{array}{l}.456 \\
(.395)\end{array}$ \\
\hline Number of elementary schools & $\begin{array}{l}-.001 \\
(.001)\end{array}$ & & $\begin{array}{l}-.001 \\
(.002)\end{array}$ & \\
\hline $\begin{array}{l}\text { Number of Catholic boys in elementary } \\
\text { schools }\end{array}$ & $\begin{array}{c}.000 \\
(.000)\end{array}$ & & $\begin{array}{c}.000 \\
(.000)\end{array}$ & \\
\hline $\begin{array}{l}\text { Number of non-Catholic boys in elementary } \\
\text { schools }\end{array}$ & $\begin{array}{c}.000 \\
(.000)\end{array}$ & & $\begin{array}{l}.000 \\
(.000)\end{array}$ & \\
\hline Number of Catholic girls in elementary schools & $\begin{array}{l}-.000 \\
(.000)\end{array}$ & & $\begin{array}{l}-.000 \\
(.001)\end{array}$ & \\
\hline $\begin{array}{l}\text { Number of non-Catholic girls in elementary } \\
\text { schools }\end{array}$ & $\begin{array}{l}-.000 \\
(.000)\end{array}$ & & $\begin{array}{l}-.000 \\
(.001)\end{array}$ & \\
\hline Number of schools of higher degrees & & $\begin{array}{l}-.005 \\
(.011)\end{array}$ & & $\begin{array}{l}-.021 \\
(.056)\end{array}$ \\
\hline $\begin{array}{l}\text { Number of Catholic boys in schools of higher } \\
\text { degrees }\end{array}$ & & $\begin{array}{c}.001 \\
(.001)\end{array}$ & & $\begin{array}{c}.001 \\
(.003)\end{array}$ \\
\hline $\begin{array}{l}\text { Number of non-Catholic boys in schools of } \\
\text { higher degrees }\end{array}$ & & $\begin{array}{l}-.001^{* *} \\
(.001)\end{array}$ & & $\begin{array}{l}-.001 \\
(.003)\end{array}$ \\
\hline $\begin{array}{l}\text { Number of Catholic girls in schools of higher } \\
\text { degrees }\end{array}$ & & $\begin{array}{l}-.000 \\
(.001)\end{array}$ & & $\begin{array}{l}-.001 \\
(.002)\end{array}$ \\
\hline $\begin{array}{l}\text { Number of non-Catholic girls in schools of } \\
\text { higher degrees }\end{array}$ & & $\begin{array}{l}-.000 \\
(.000)\end{array}$ & & $\begin{array}{c}.000 \\
(.001)\end{array}$ \\
\hline Hansen's $J$-statistic & $\begin{array}{l}8.576 \\
{[.661]}\end{array}$ & $\begin{array}{l}10.328 \\
{[.501]}\end{array}$ & $\begin{array}{l}9.390 \\
{[.496]}\end{array}$ & $\begin{array}{l}9.155 \\
{[.517]}\end{array}$ \\
\hline
\end{tabular}

Notes: Standard errors in parentheses are clustered by state. The notation $* * *$ is $\mathrm{p}<0.01, * *$ is $\mathrm{p}<0.05, *$ is $\mathrm{p}<0.10 . \quad p$-values in square brackets. Regressions include all controls as before. Number of observations and $\mathrm{R}^{2}$ in the range of those reported above. 
Appendix Table 1: Regressions with controls for endogeneity of missions for boys. Dependent variable: height-for-age

\begin{tabular}{|c|c|c|c|c|c|c|}
\hline & & All States & & States & Christian & sence \\
\hline & $0-11$ & $12-23$ & $24-35$ & $0-11$ & $12-23$ & $24-35$ \\
\hline Christian & 3.126 & .365 & 3.573 & 4.553 & -3.614 & -.582 \\
\hline & (2.757) & $(2.170)$ & (2.707) & $(3.027)$ & $(2.939)$ & $(2.320)$ \\
\hline Upper-caste Hindu & $.505^{*}$ & .140 & .151 & $1.280^{*}$ & -.192 & -.045 \\
\hline & $(.278)$ & $(.143)$ & $(.149)$ & $(.718)$ & $(.369)$ & $(.348)$ \\
\hline Muslim & .358 & .136 & .175 & $1.369^{*}$ & -.420 & .041 \\
\hline & $(.311)$ & $(.144)$ & $(.194)$ & $(.789)$ & $(.393)$ & $(.401)$ \\
\hline Order of birth & $-.104 * * *$ & -.014 & $-.072 * * *$ & .084 & .082 & -.063 \\
\hline & $(.030)$ & $(.050)$ & $(.015)$ & (.094) & $(.088)$ & (.094) \\
\hline Dummy for child had diarrhea last two & $.205^{*}$ & -.086 & -.154 & .309 & -.007 & .070 \\
\hline weeks & $(.080)$ & $(.074)$ & $(.097)$ & $(.211)$ & $(.172)$ & $(.188)$ \\
\hline Dummy for child had cough last two weeks & .073 & .015 & .047 & .006 & .045 & .060 \\
\hline & $(.060)$ & $(.033)$ & $(.037)$ & $(.153)$ & $(.115)$ & $(.142)$ \\
\hline Dummy for child was nursed & $.198 * * *$ & -.064 & -.132 & .101 & -.035 & .138 \\
\hline & $(.070)$ & $(.087)$ & $(.140)$ & $(.320)$ & $(.233)$ & $(.200)$ \\
\hline Child was exposed to Ramadan in utero & .172 & -.237 & -.242 & $.713^{*}$ & .516 & .041 \\
\hline & $(.173)$ & $(.331)$ & $(.140)$ & $(.394)$ & $(.430)$ & $(.253)$ \\
\hline Dummy for had prenatal or antenatal check & $.190 * *$ & $.098 * *$ & $.151 * *$ & .186 & .141 & -.509 \\
\hline with doctor & $(.078)$ & $(.049)$ & $(.068)$ & $(.220)$ & $(.133)$ & $(.406)$ \\
\hline Age of woman & $.216^{* *}$ & -.006 & $-.108 * *$ & $.428 *$ & -.250 & $.380 * * *$ \\
\hline & $(.098)$ & $(.106)$ & $(.048)$ & $(.230)$ & $(.190)$ & $(.127)$ \\
\hline Age of woman at first birth & $-.044 * * *$ & .023 & $-.049 * * *$ & -.029 & $.063 *$ & -.049 \\
\hline & $(.014)$ & $(.018)$ & $(.012)$ & $(.043)$ & $(.035)$ & $(.042)$ \\
\hline Age of woman at first marriage & $-.158 *$ & .004 & $.145^{* * *}$ & $-.384 *$ & .225 & .043 \\
\hline & $(.089)$ & $(.107)$ & $(.047)$ & $(.230)$ & $(.198)$ & $(.225)$ \\
\hline Woman has had a miscarriage, stillbirth or & .007 & .077 & -.128 & -.168 & $.441 * *$ & -.218 \\
\hline abortion & $(.083)$ & $(.108)$ & $(.086)$ & $(.231)$ & $(.207)$ & $(.207)$ \\
\hline
\end{tabular}


Dummy for woman is literate

Woman has some or all primary school

Woman has some secondary school

Woman has completed secondary school or higher

Child was large at birth

Child was average at birth

Woman is currently working

Woman works in farming, fishing, hunting or logging

Number of children five years old and under

Number of years since first marriage

Woman watches cinema at least once a month

Woman listens to radio every week

Husband's age

Dummy for husband has no education

\begin{tabular}{|c|c|c|c|c|c|}
\hline $.568 * * *$ & .222 & -.077 & $1.055 * * *$ & .137 & $.531 *$ \\
\hline$(.137)$ & $(.103)$ & $(.089)$ & $(.245)$ & $(.244)$ & $(.275)$ \\
\hline$-.330 * *$ & -.032 & -.125 & $-.842 * * *$ & -.017 & -.378 \\
\hline$(.165)$ & $(.086)$ & $(.140)$ & $(.249)$ & $(.226)$ & $(.277)$ \\
\hline-.465 & -.202 & .268 & $-1.312 * * *$ & -.212 & -.180 \\
\hline$(.285)$ & $(.181)$ & $(.172)$ & $(.434)$ & $(.330)$ & $(.332)$ \\
\hline$-.852 * * *$ & .088 & $.638 * *$ & $-1.573^{* *}$ & -.054 & .262 \\
\hline$(.277)$ & $(.174)$ & $(.281)$ & $(.656)$ & $(.599)$ & $(.536)$ \\
\hline $.665 * * *$ & $.444 * * *$ & $.244 * * *$ & $.788 * * *$ & $.546 * * *$ & $.283^{*}$ \\
\hline (.104) & $(.083)$ & $(.051)$ & $(.198)$ & $(.153)$ & $(.160)$ \\
\hline $280 * * *$ & $.281 * * *$ & .085 & .208 & .159 & -.010 \\
\hline$(.058)$ & $(.050)$ & $(.075)$ & (.199) & $(.136)$ & $(.143)$ \\
\hline .016 & -.070 & -.077 & .105 & -.082 & .062 \\
\hline$(.085)$ & $(.058)$ & $(.089)$ & $(.185)$ & $(.123)$ & $(.135)$ \\
\hline-.011 & -.068 & .062 & .250 & $.232 *$ & .060 \\
\hline$(.094)$ & $(.079)$ & $(.117)$ & $(.192)$ & $(.123)$ & $(.147)$ \\
\hline .023 & $-.042 *$ & -.009 & $-.125^{*}$ & .013 & $-.113 * *$ \\
\hline$(.026)$ & $(.025)$ & $(.023)$ & $(.073)$ & $(.054)$ & $(.055)$ \\
\hline$-.161 *$ & -.004 & $.133 * * *$ & $-.448 *$ & .213 & .012 \\
\hline$(.096)$ & $(.103)$ & $(.046)$ & $(.229)$ & (.194) & $(.225)$ \\
\hline .191 & $.151 * * *$ & .112 & .266 & .149 & .019 \\
\hline$(.124)$ & $(.055)$ & $(.074)$ & $(.224)$ & $(.138)$ & $(.151)$ \\
\hline .030 & .057 & -.044 & .181 & $.365^{* * *} *$ & .066 \\
\hline$(.079)$ & $(.112)$ & (.089) & $(.142)$ & $(.103)$ & $(.112)$ \\
\hline-.003 & $.008 * *$ & -.003 & $.034 * *$ & .006 & .015 \\
\hline$(.004)$ & $(.004)$ & $(.003)$ & $(.017)$ & $(.011)$ & $(.018)$ \\
\hline .039 & $.108 * *$ & .097 & .179 & -.047 & $.278 *$ \\
\hline$(.165)$ & $(.049)$ & $(.093)$ & $(.222)$ & (.187) & $(.161)$ \\
\hline
\end{tabular}




\begin{tabular}{|c|c|c|c|c|c|c|}
\hline $\begin{array}{l}\text { Dummy for husband has some or all primary } \\
\text { school }\end{array}$ & $\begin{array}{l}-.007 \\
(.167)\end{array}$ & $\begin{array}{l}.200 * * \\
(.089)\end{array}$ & $\begin{array}{l}.217 * * * \\
(.061)\end{array}$ & $\begin{array}{l}-.171 \\
(.363)\end{array}$ & $\begin{array}{c}.152 \\
(.202)\end{array}$ & $\begin{array}{c}.240 \\
(.174)\end{array}$ \\
\hline Dummy for husband has completed & .129 & $.203^{*}$ & $.329 * * *$ & .299 & .317 & .303 \\
\hline secondary school or higher & $(.153)$ & $(.108)$ & $(.065)$ & $(.259)$ & $(.297)$ & $(.236)$ \\
\hline $\begin{array}{l}\text { Dummy for husband works outside of the } \\
\text { home }\end{array}$ & $\begin{array}{l}-.236 \\
(.267)\end{array}$ & $\begin{array}{l}-.112 \\
(.208)\end{array}$ & $\begin{array}{l}-.149 \\
(.223)\end{array}$ & $\begin{array}{r}-1.228 * \\
(.660)\end{array}$ & $\begin{array}{l}-.721 \\
(.458)\end{array}$ & $\begin{array}{l}.097 \\
(.588)\end{array}$ \\
\hline $\begin{array}{l}\text { Husband works in farming, fishing, hunting } \\
\text { or logging }\end{array}$ & $\begin{array}{c}.053 \\
(.087)\end{array}$ & $\begin{array}{c}-.072 * * \\
(.039)\end{array}$ & $\begin{array}{l}-.096 \\
(.080)\end{array}$ & $\begin{array}{l}-.081 \\
(.198)\end{array}$ & $\begin{array}{l}-.115 \\
(.125)\end{array}$ & $\begin{array}{l}.243 * * \\
(.123)\end{array}$ \\
\hline Rural household & $\begin{array}{l}.170 * * \\
(.078)\end{array}$ & $\begin{array}{l}-.048 \\
(.083)\end{array}$ & $\begin{array}{l}-.003 \\
(.128)\end{array}$ & $\begin{array}{l}.472 * * \\
(.217)\end{array}$ & $\begin{array}{c}.064 \\
(.168)\end{array}$ & $\begin{array}{l}-.261 \\
(.188)\end{array}$ \\
\hline Age of household head & $\begin{array}{c}.000 \\
(.003)\end{array}$ & $\begin{array}{l}.004 * * \\
(.002)\end{array}$ & $\begin{array}{c}.004 \\
(.002)\end{array}$ & $\begin{array}{c}-.009 * * \\
(.004)\end{array}$ & $\begin{array}{l}-.002 \\
(.004)\end{array}$ & $\begin{array}{l}-.007 \\
(.005)\end{array}$ \\
\hline Dummy for household has male head & $\begin{array}{l}-.192 \\
(.133)\end{array}$ & $\begin{array}{c}.071 \\
(.044)\end{array}$ & $\begin{array}{l}.121^{*} \\
(.150)\end{array}$ & $\begin{array}{l}-.303 \\
(.283)\end{array}$ & $\begin{array}{c}.037 \\
(.207)\end{array}$ & $\begin{array}{l}-.034 \\
(.314)\end{array}$ \\
\hline $\begin{array}{l}\text { Dummy for household owns a car } \\
\text { or a refrigerator }\end{array}$ & $\begin{array}{l}-.029 \\
(.684)\end{array}$ & $\begin{array}{c}-.761 * * * \\
(.291)\end{array}$ & $\begin{array}{l}.313 \\
(.584)\end{array}$ & $\begin{array}{c}.476 \\
(.467)\end{array}$ & $\begin{array}{l}-.318 \\
(.445)\end{array}$ & $\begin{array}{l}.724 * \\
(.410)\end{array}$ \\
\hline Dummy for household owns motorcycle & $\begin{array}{l}-.046 \\
(.101)\end{array}$ & $\begin{array}{l}.159 \\
(.107)\end{array}$ & $\begin{array}{l}.264 * * * \\
(.077)\end{array}$ & $\begin{array}{l}-.064 \\
(.258)\end{array}$ & $\begin{array}{c}.121 \\
(.238)\end{array}$ & $\begin{array}{l}.672 * * \\
(.300)\end{array}$ \\
\hline Dummy for household owns electricity & $\begin{array}{c}.040 \\
(.151)\end{array}$ & $\begin{array}{c}.056 \\
(.073)\end{array}$ & $\begin{array}{c}.106 \\
(.115)\end{array}$ & $\begin{array}{l}.298 * \\
(.174)\end{array}$ & $\begin{array}{c}.169 \\
(.131)\end{array}$ & $\begin{array}{c}.134 \\
(.159)\end{array}$ \\
\hline Source of drinking water: ground water & $\begin{array}{c}.055 \\
(.141)\end{array}$ & $\begin{array}{c}.099 \\
(.093)\end{array}$ & $\begin{array}{l}-.015 \\
(.075)\end{array}$ & $\begin{array}{c}.329 \\
(.217)\end{array}$ & $\begin{array}{c}.032 \\
(.145)\end{array}$ & $\begin{array}{l}-.056 \\
(.166)\end{array}$ \\
\hline Source of drinking water: well water & $\begin{array}{c}.089 \\
(.128)\end{array}$ & $\begin{array}{c}.085 \\
(.085)\end{array}$ & $\begin{array}{c}.142 \\
(.112)\end{array}$ & $\begin{array}{c}.299 \\
(.235)\end{array}$ & $\begin{array}{c}.306 \\
(.164)\end{array}$ & $\begin{array}{c}.141 \\
(.193)\end{array}$ \\
\hline Source of drinking water: surface water & $\begin{array}{c}.063 \\
(.129)\end{array}$ & $\begin{array}{c}.194 \\
(.144)\end{array}$ & $\begin{array}{l}-.148 \\
(.215)\end{array}$ & $\begin{array}{c}.052 \\
(.389)\end{array}$ & $\begin{array}{c}.041 \\
(.381)\end{array}$ & $\begin{array}{c}.239 \\
(.345)\end{array}$ \\
\hline $\begin{array}{l}\text { Source of drinking water: rainwater, tanker } \\
\text { truck, other }\end{array}$ & $\begin{array}{c}.089 \\
(.317)\end{array}$ & $\begin{array}{l}-.065 \\
(.256)\end{array}$ & $\begin{array}{c}.255 \\
(.256)\end{array}$ & $\begin{array}{l}.250 \\
(.556)\end{array}$ & $\begin{array}{l}-.208 \\
(.375)\end{array}$ & $\begin{array}{l}.242 \\
(.319)\end{array}$ \\
\hline
\end{tabular}


Toilet facility is: flush toilet

Toilet facility is: pit toilet/latrine

Toilet facility is: no facility/bush/field

Years lived in place of residence

Per-capita GDP

Wheat crop area

Summer rice crop area

Winter rice crop area

Autumn rice crop area

Rainfall in millimeters $\left(\times 10^{-2}\right)$

Number of cities at or above 1500 feet in

Number of cities on railway lines in district as of 1893

Number of cities on navigable canals in district as of 1893

\begin{tabular}{cccccc}
-.139 & $2.500 * * *$ & $1.783 * * *$ & $2.721 * * *$ & .104 & .023 \\
$(1.203)$ & $(.256)$ & $(.304)$ & $(.919)$ & $(.219)$ & $(.167)$ \\
-.259 & $2.417 * * *$ & $1.811 * * *$ & $2.711^{* * *}$ & -.003 & $.584 *$ \\
$(1.170)$ & $(.236)$ & $(.277)$ & $(.911)$ & $(.192)$ & $(.316)$ \\
-.626 & $2.249 * * *$ & $1.669 * * *$ & $2.063 * *$ & & \\
$(1.212)$ & $(.275)$ & $(.315)$ & $(.840)$ & & \\
.000 & $.006 * * *$ & -.001 & -.004 & .004 & -.003 \\
$(.004)$ & $(.002)$ & $(.002)$ & $(.005)$ & $(.003)$ & $(.003)$ \\
$.004 * * *$ & -.001 & -.002 & -.157 & .005 & -.001 \\
$(.001)$ & $(.001)$ & $(.002)$ & $(.104)$ & $(.018)$ & $(.003)$ \\
-7.845 & -2.124 & $22.901 * * *$ & -83.883 & 36.886 & 56.546 \\
$(12.928)$ & $(13.623)$ & $(8.597)$ & $(66.298)$ & $(60.561)$ & $(172.741)$ \\
-.939 & -13.170 & -17.875 & 32.858 & -25.459 & 51.108 \\
$(8.254)$ & $(13.035)$ & $(28.237)$ & $(67.401)$ & $(57.273)$ & $(135.543)$ \\
.857 & 8.633 & .154 & -1017.850 & 20.181 & $-7.425 *$ \\
$(.624)$ & $(6.931)$ & $(.498)$ & $(684.880)$ & $(116.504)$ & $(4.222)$ \\
-1.668 & 1.849 & $-2.909 * *$ & 13.388 & -3.778 & -.923 \\
$(3.096)$ & $(4.567)$ & $(1.237)$ & $(13.336)$ & $(8.095)$ & $(10.747)$ \\
.008 & -.062 & .035 & -.041 & -.034 & -.060 \\
$(.059)$ & $(.049)$ & $(.048)$ & $(.069)$ & $(.062)$ & $(.082)$ \\
.004 & .001 & -.002 & $.018 * *$ & -.006 & -.007 \\
$(.005)$ & $(.003)$ & $(.005)$ & $(.008)$ & $(.009)$ & $(.008)$ \\
.023 & .009 & .003 & .013 & .013 & .006 \\
$(.014)$ & $(.010)$ & $(.020)$ & $(.029)$ & $(.021)$ & $(.015)$ \\
-.001 & -.001 & .011 & .026 & $-.042 * *$ & -.005 \\
$(.022)$ & $(.012)$ & $(.014)$ & $(.055)$ & $(.020)$ & $(.012)$ \\
\hline
\end{tabular}

Notes: Standard errors in parentheses are clustered by state. The notation $* * *$ is $\mathrm{p}<0.01, * *$ is $\mathrm{p}<0.05, *$ is $\mathrm{p}<0.10$. 
Appendix Table 2: Regressions with controls for endogeneity of missions for girls. Dependent variable: height-for-age

\begin{tabular}{|c|c|c|c|c|c|c|}
\hline & & All States & & States & Christian & sence \\
\hline & $0-11$ & $12-23$ & $24-35$ & $0-11$ & $12-23$ & $24-35$ \\
\hline Christian & $3.702 *$ & -.248 & -.132 & $4.106^{*}$ & .363 & -.017 \\
\hline & $(2.170)$ & $(1.756)$ & (1.509) & $(2.314)$ & $(1.536)$ & (1.178) \\
\hline Upper-caste Hindu & $.248 *$ & -.005 & -.040 & $.779 * * *$ & .327 & -.059 \\
\hline & $(.138)$ & $(.195)$ & $(.103)$ & $(.296)$ & $(.300)$ & $(.200)$ \\
\hline Muslim & .215 & -.076 & -.200 & $.728 *$ & -.028 & -.076 \\
\hline & $(.138)$ & $(.114)$ & $(.181)$ & $(.405)$ & $(.326)$ & $(.270)$ \\
\hline Order of birth & -.010 & -.014 & $-.119 * * *$ & -.154 & -.037 & $-.173 *$ \\
\hline & $(.049)$ & $(.034)$ & $(.034)$ & (.109) & $(.075)$ & $(.092)$ \\
\hline Dummy for child had diarrhea last two & -.076 & -.131 & $-.107 * *$ & .080 & .105 & -.197 \\
\hline weeks & $(.082)$ & $(.082)$ & $(.054)$ & $(.152)$ & $(.122)$ & $(.168)$ \\
\hline Dummy for child had cough last two weeks & .115 & $-.181 * * *$ & $-.126 * *$ & -.094 & -.097 & -.187 \\
\hline & $(.077)$ & $(.062)$ & $(.058)$ & $(.177)$ & $(.089)$ & $(.133)$ \\
\hline Dummy for child was nursed & $.397 * *$ & -.068 & -.060 & .146 & -.208 & -.021 \\
\hline & $(.189)$ & $(.078)$ & $(.111)$ & $(.268)$ & $(.235)$ & $(.240)$ \\
\hline Child was exposed to Ramadan in utero & -.199 & .139 & .095 & -.178 & $1.233 * *$ & .199 \\
\hline & $(.287)$ & $(.333)$ & $(.118)$ & $(.353)$ & $(.493)$ & $(.350)$ \\
\hline Dummy for had prenatal or antenatal check & .097 & $.342 * *$ & .018 & -.042 & .061 & -.144 \\
\hline with doctor & $(.085)$ & $(.145)$ & $(.047)$ & $(.129)$ & $(.119)$ & $(.127)$ \\
\hline Age of woman & $.305 * * *$ & .058 & $.093 *$ & .388 & .007 & .031 \\
\hline & $(.104)$ & $(.142)$ & $(.054)$ & $(.239)$ & $(.153)$ & $(.172)$ \\
\hline Age of woman at first birth & .001 & .024 & $-.028 *$ & -.060 & $.071 *$ & -.051 \\
\hline & $(.024)$ & $(.022)$ & $(.014)$ & $(.050)$ & $(.039)$ & $(.042)$ \\
\hline Age of woman at first marriage & $-.292 * * *$ & -.054 & -.040 & -.384 & -.049 & .044 \\
\hline & $(.113)$ & $(.160)$ & $(.058)$ & $(.248)$ & $(.157)$ & $(.171)$ \\
\hline Woman has had a miscarriage, stillbirth or & $.117 *$ & .072 & -.018 & .037 & .092 & .051 \\
\hline abortion & $(.061)$ & $(.055)$ & $(.054)$ & $(.224)$ & $(.143)$ & $(.183)$ \\
\hline
\end{tabular}




\begin{tabular}{|c|c|c|c|c|c|c|}
\hline Dummy for woman is literate & $\begin{array}{c}.443 * * * \\
(.146)\end{array}$ & $\begin{array}{c}.073 \\
(.120)\end{array}$ & $\begin{array}{c}.133 \\
(.171)\end{array}$ & $\begin{array}{l}.654 * * \\
(.297)\end{array}$ & $\begin{array}{c}.344 \\
(.216)\end{array}$ & $\begin{array}{c}.273 \\
(.231)\end{array}$ \\
\hline \multirow[t]{2}{*}{ Woman has some or all primary school } & $-.288 * *$ & .137 & -.110 & -.068 & .021 & -.278 \\
\hline & $(.124)$ & $(.088)$ & $(.121)$ & $(.303)$ & $(.179)$ & $(.202)$ \\
\hline \multirow[t]{2}{*}{ Woman has some secondary school } & -.271 & .123 & .132 & -.075 & -.267 & -.220 \\
\hline & $(.179)$ & $(.148)$ & $(.212)$ & $(.392)$ & $(.290)$ & $(.303)$ \\
\hline \multirow{2}{*}{$\begin{array}{l}\text { Woman has completed secondary school } \\
\text { or higher }\end{array}$} & -.182 & .039 & $.474 * *$ & .283 & .348 & .279 \\
\hline & $(.273)$ & $(.163)$ & $(.207)$ & $(.708)$ & $(.554)$ & $(.630)$ \\
\hline \multirow[t]{2}{*}{ Child was large at birth } & $.626 * * *$ & $.395 * * *$ & $.377 * * *$ & $.572 * * *$ & $.396 * *$ & $.484 * * *$ \\
\hline & $(.084)$ & $(.144)$ & $(.073)$ & $(.197)$ & $(.175)$ & $(.165)$ \\
\hline \multirow{2}{*}{ Child was average at birth } & $.488 * * *$ & $.143 *$ & .060 & $.482 * * *$ & .175 & .122 \\
\hline & $(.089)$ & $(.073)$ & $(.039)$ & $(.151)$ & $(.116)$ & $(.104)$ \\
\hline \multirow[t]{2}{*}{ Woman is currently working } & $-.148 *$ & $-.217 * * *$ & -.157 & -.216 & -.123 & -.166 \\
\hline & $(.083)$ & $(.070)$ & $(.096)$ & $(.162)$ & $(.136)$ & $(.138)$ \\
\hline \multirow{2}{*}{$\begin{array}{l}\text { Woman works in farming, fishing, hunting } \\
\text { or logging }\end{array}$} & -.032 & -.065 & -.063 & .217 & .003 & -.122 \\
\hline & $(.121)$ & $(.119)$ & $(.082)$ & $(.146)$ & $(.110)$ & $(.130)$ \\
\hline \multirow[t]{2}{*}{ Number of children five years old or under } & -.017 & -.027 & .003 & .078 & .005 & -.007 \\
\hline & $(.031)$ & $(.019)$ & $(.029)$ & $(.084)$ & $(.055)$ & $(.051)$ \\
\hline \multirow[t]{2}{*}{ Number of years since first marriage } & $-.293 * * *$ & -.065 & -.059 & -.370 & -.035 & .024 \\
\hline & $(.107)$ & $(.147)$ & $(.051)$ & $(246)$ & $(.157)$ & $(.172)$ \\
\hline \multirow{2}{*}{$\begin{array}{l}\text { Woman watches cinema at least once a } \\
\text { month }\end{array}$} & -.011 & .007 & -.064 & .025 & .144 & -.076 \\
\hline & $(.117)$ & $(.142)$ & $(.110)$ & $(.184)$ & $(.133)$ & $(.147)$ \\
\hline \multirow[t]{2}{*}{ Woman listens to radio every week } & $.144 * * *$ & -.005 & .063 & .064 & -.038 & .019 \\
\hline & $(.049)$ & $(.102)$ & $(.091)$ & $(.144)$ & $(.117)$ & $(.113)$ \\
\hline \multirow[t]{2}{*}{ Husband's age } & -.002 & $.007 *$ & -.001 & $.032 * *$ & .003 & $-.017 *$ \\
\hline & $(.005)$ & $(.004)$ & $(.006)$ & $(.013)$ & $(.015)$ & $(.010)$ \\
\hline \multirow[t]{2}{*}{ Dummy for husband has no education } & -.048 & -.041 & .124 & -.103 & .165 & .148 \\
\hline & $(.066)$ & $(.065)$ & $(.081)$ & $(.206)$ & $(.146)$ & $(.161)$ \\
\hline
\end{tabular}




\begin{tabular}{|c|c|c|c|c|c|c|}
\hline $\begin{array}{l}\text { Dummy for husband has some or all prelim. } \\
\text { school }\end{array}$ & $\begin{array}{l}.151^{*} \\
(.078)\end{array}$ & $\begin{array}{l}.116 \\
(.077)\end{array}$ & $\begin{array}{c}.170 * * * \\
(.065)\end{array}$ & $\begin{array}{l}.480 * \\
(.251)\end{array}$ & $\begin{array}{l}.251 \\
(.157)\end{array}$ & $\begin{array}{l}.426^{* *} \\
(.170)\end{array}$ \\
\hline \multirow{2}{*}{$\begin{array}{l}\text { Dummy for husband has completed } \\
\text { secondary school or higher }\end{array}$} & $.195^{* *}$ & .102 & $.225 * *$ & $.445^{*}$ & .136 & .275 \\
\hline & $(.085)$ & $(.092)$ & $(.088)$ & $(.227)$ & $(.239)$ & $(.218)$ \\
\hline \multirow{2}{*}{$\begin{array}{l}\text { Dummy for husband works outside of the } \\
\text { home }\end{array}$} & -.179 & $-.297 *$ & .067 & $-1.230 * *$ & .116 & $-.755 * *$ \\
\hline & $(.260)$ & $(.153)$ & $(.212)$ & $(.624)$ & $(.281)$ & $(.314)$ \\
\hline \multirow{2}{*}{$\begin{array}{l}\text { Husband works in farming, fishing, hunting } \\
\text { or logging }\end{array}$} & .056 & .001 & .048 & $.381 * *$ & .036 & -.010 \\
\hline & $(.124)$ & $(.064)$ & $(.081)$ & $(.161)$ & $(.145)$ & $(.127)$ \\
\hline \multirow[t]{2}{*}{ Rural household } & .086 & .055 & -.017 & -.091 & .149 & -.062 \\
\hline & $(.105)$ & $(.053)$ & $(.112)$ & $(.228)$ & $(.151)$ & $(.163)$ \\
\hline \multirow[t]{2}{*}{ Age of household head } & .001 & .002 & $-.004 *$ & $-.011 *$ & .001 & -.004 \\
\hline & $(.003)$ & $(.003)$ & $(.002)$ & $(.005)$ & $(.004)$ & $(.003)$ \\
\hline \multirow[t]{2}{*}{ Dummy for household has male head } & $.177 * * *$ & -.120 & .053 & .150 & -.039 & .202 \\
\hline & $(.068)$ & $(.115)$ & $(.093)$ & $(.250)$ & $(.262)$ & $(.222)$ \\
\hline \multirow{2}{*}{$\begin{array}{l}\text { Dummy for household owns a car } \\
\text { or a refrigerator }\end{array}$} & -.628 & -.391 & -.354 & -.171 & .027 & $-1.137 * *$ \\
\hline & $(.399)$ & $(.393)$ & $(.411)$ & $(.469)$ & $(1.515)$ & $(.506)$ \\
\hline \multirow[t]{2}{*}{ Dummy for household owns motorcycle } & -.042 & .169 & $.317 * * *$ & -.340 & .032 & $.433 * * *$ \\
\hline & $(.138)$ & $(.154)$ & $(.070)$ & $(.389)$ & $(.237)$ & $(.163)$ \\
\hline \multirow[t]{2}{*}{ Dummy for household owns electricity } & -.047 & -.042 & .048 & -.048 & -.008 & .009 \\
\hline & $(.102)$ & $(.084)$ & $(.048)$ & $(.200)$ & $(.121)$ & $(.156)$ \\
\hline \multirow[t]{2}{*}{ Source of drinking water: ground water } & $.131 *$ & -.031 & .040 & -.077 & -.122 & -.071 \\
\hline & $(.070)$ & $(.116)$ & $(.072)$ & $(.209)$ & $(.151)$ & $(.122)$ \\
\hline \multirow[t]{2}{*}{ Source of drinking water: well water } & -.019 & -.088 & $.225 * *$ & -.009 & $-.511 * * *$ & .332 \\
\hline & $(.069)$ & $(.103)$ & $(.110)$ & $(.251)$ & $(.143)$ & $(.244)$ \\
\hline \multirow[t]{2}{*}{ Source of drinking water: surface water } & -.014 & -.216 & -.100 & .380 & .181 & .205 \\
\hline & $(.223)$ & $(.248)$ & $(.152)$ & $(.489)$ & $(.317)$ & $(.391)$ \\
\hline \multirow{2}{*}{$\begin{array}{l}\text { Source of drinking water: rainwater, tanker } \\
\text { truck, other }\end{array}$} & .057 & -.244 & .114 & .246 & -.673 & -.183 \\
\hline & $(.250)$ & $(.266)$ & $(.446)$ & $(.507)$ & $(.429)$ & $(.483)$ \\
\hline
\end{tabular}


Toilet facility is: flush toilet

Toilet facility is: pit toilet/latrine

Toilet facility is: no facility/bush/field

Years lived in place of residence

Per-capita GDP

Wheat crop area

Summer rice crop area

Winter rice crop area

Autumn rice crop area

Rainfall in millimeters $\left(\times 10^{-2}\right)$

Number of cities at or above 1500 feet in district as of 1893

Number of cities on railway lines in district as of 1893

Number of cities on navigable canals in district as of 1893

\begin{tabular}{|c|c|c|c|c|c|}
\hline$-.660 * * *$ & -.080 & -.157 & -.551 & $.376^{* *} *$ & .269 \\
\hline$(.226)$ & $(.660)$ & $(.165)$ & $(.539)$ & $(.163)$ & $(.178)$ \\
\hline$-.870 * * *$ & -.407 & -.230 & -.453 & -.203 & $.357 * *$ \\
\hline$(.250)$ & $(.711)$ & $(.161)$ & $(.555)$ & $(.229)$ & $(.162)$ \\
\hline$-1.069 * * *$ & -.371 & $-.441 * *$ & -.782 & & \\
\hline$(.255)$ & $(.681)$ & $(.180)$ & $(.520)$ & & \\
\hline .001 & -.001 & .002 & .002 & -.004 & .002 \\
\hline$(.003)$ & $(.003)$ & $(.002)$ & $(.004)$ & $(.003)$ & $(.003)$ \\
\hline $.004 * * *$ & $.005 * * *$ & .000 & .020 & .017 & .003 \\
\hline$(.001)$ & $(.001)$ & $(.001)$ & $(.080)$ & $(.018)$ & $(.002)$ \\
\hline $16.834 * *$ & 9.673 & -10.447 & 43.100 & 28.433 & 104.128 \\
\hline$(8.317)$ & $(6.066)$ & $(12.590)$ & $(40.496)$ & $(52.190)$ & $(153.772)$ \\
\hline-8.643 & 14.997 & -6.731 & -8.217 & -46.855 & 21.399 \\
\hline (8.136) & $(9.225)$ & $(13.940)$ & (48.129) & $(64.866)$ & (95.021) \\
\hline-.038 & $7.242 *$ & $.805^{* *}$ & 148.008 & 102.570 & -.030 \\
\hline$(.464)$ & $(4.288)$ & $(.392)$ & $(514.192)$ & (115.386) & $(3.393)$ \\
\hline $3.916 * *$ & $4.259 * *$ & $-5.683^{*}$ & 8.394 & 10.957 & -.639 \\
\hline$(1.640)$ & $(1.924)$ & (3.049) & $(7.418)$ & (7.342) & (10.182) \\
\hline .000 & -.017 & .056 & .006 & .003 & .048 \\
\hline$(.048)$ & $(.058)$ & $(.035)$ & $(.073)$ & (.068) & (.087) \\
\hline .001 & .001 & -.006 & -.007 & -.005 & $-.020 * * *$ \\
\hline$(.007)$ & $(.005)$ & $(.006)$ & $(.009)$ & $(.007)$ & $(.007)$ \\
\hline .021 & -.021 & .014 & .001 & $-.026^{*}$ & .008 \\
\hline (.019) & $(.017)$ & $(.014)$ & $(.027)$ & $(.016)$ & $(.016)$ \\
\hline$-.023 *$ & -.002 & -.005 & -.029 & .008 & -.004 \\
\hline$(.013)$ & $(.014)$ & $(.010)$ & $(.029)$ & $(.020)$ & $(.019)$ \\
\hline
\end{tabular}

Notes: Standard errors in parentheses are clustered by state or region. The notation $* * *$ is $\mathrm{p}<0.01, * *$ is $\mathrm{p}<0.05, *$ is $\mathrm{p}<0.10$. 